\title{
Air Pollution Control Technology for Municipal Solid Waste-to-Energy Conversion Facilities: Capabilities and Research Needs
}

September 1980
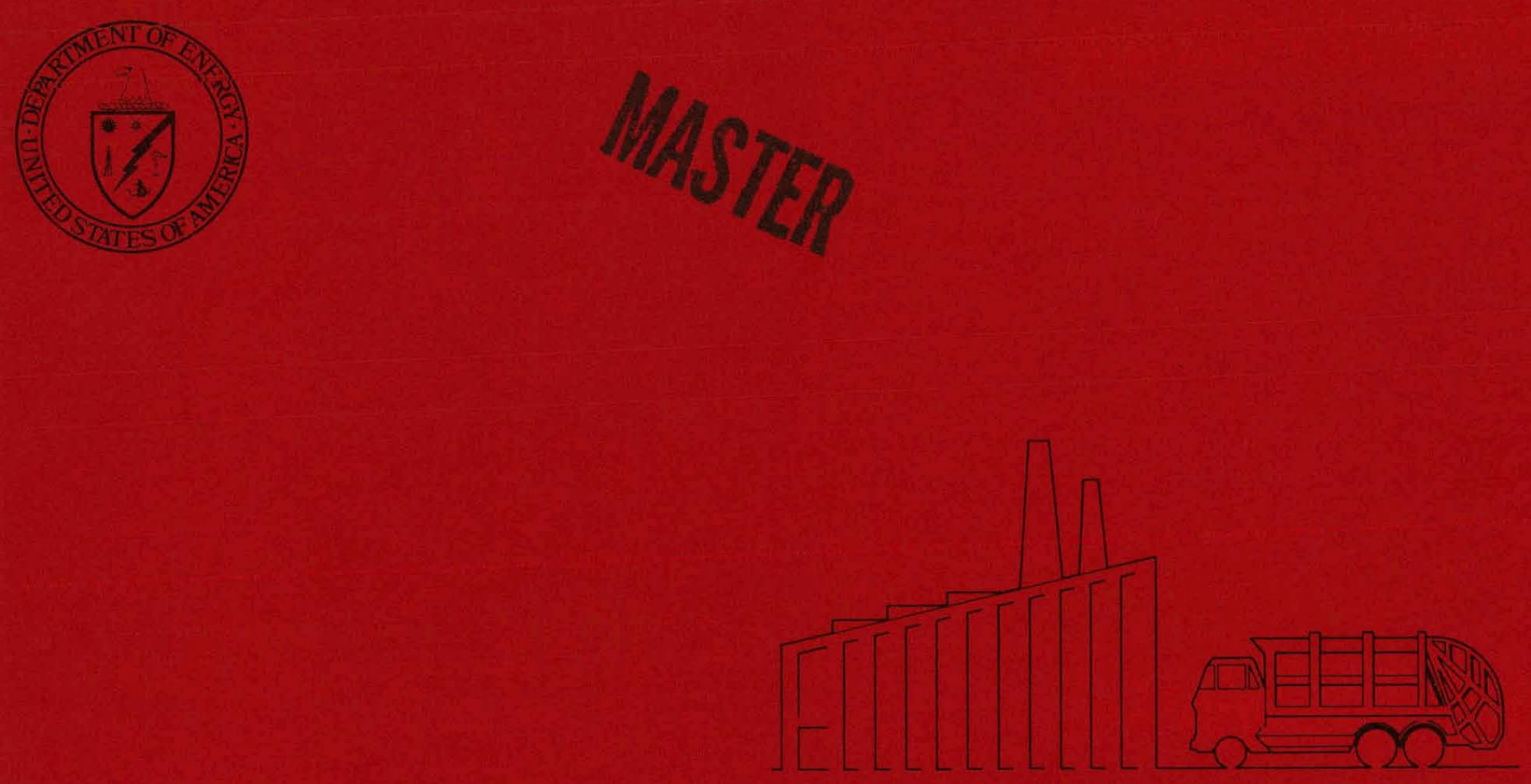

Prepared for:

U.S. Department of Energy Assistant Secretary for Environment Office of Environmental Compliance and Overview Environmental and Safety Engineering Division 


\section{DISCLAIMER}

This report was prepared as an account of work sponsored by an agency of the United States Government. Neither the United States Government nor any agency Thereof, nor any of their employees, makes any warranty, express or implied, or assumes any legal liability or responsibility for the accuracy, completeness, or usefulness of any information, apparatus, product, or process disclosed, or represents that its use would not infringe privately owned rights. Reference herein to any specific commercial product, process, or service by trade name, trademark, manufacturer, or otherwise does not necessarily constitute or imply its endorsement, recommendation, or favoring by the United States Government or any agency thereof. The views and opinions of authors expressed herein do not necessarily state or reflect those of the United States Government or any agency thereof. 


\section{DISCLAIMER}

Portions of this document may be illegible in electronic image products. Images are produced from the best available original document. 
Printed in the United States of America Available from

National Technical Information Service U.S. Department of Commerce

5285 Port Royal Road

Springfield, VA 22161

NTIS price codes

Printed Copy: $\quad \$ 7.00$

Microfiche Copy: $\quad \$ 3.50$ 


\section{Air Pollution Control Technology for Municipal Solid Waste-to-Energy Conversion Facilities: Capabilities and Research Needs}

September 1980

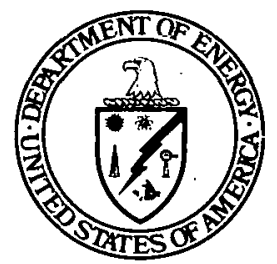

Prepared by:

Joseph F. Lynch

James C. Young

Prepared for:

U.S. Department of Energy

Assistant Secretary for Environment Office of Environmental Compliance and Overview Environmental and Safety Engineering Division Washington, D.C. 20545

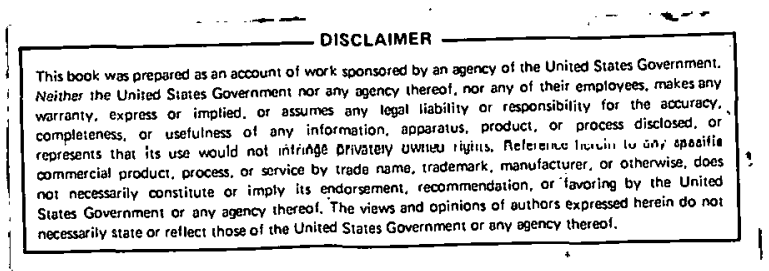


i

\section{THIS PAGE}

\section{WAS INTENTIONALLY LEFT BLANK}


TABLE OF CONTENTS

ACKNOWLEDGEMENTS

iv

LIST OF TABLES

$\mathbf{v}$

LIST OF FIGURES

v

EXECUTIVE SUMMARY

INTRODUCTION

CONCLUSIONS AND RECOMMENDATIONS

General Research Needs Applicable to Waste-to-Energy Systems

Specific Mass-Incineration Research Needs

Specific Co-Firing Research Needs

Specific Pyrolysis Research Needs

SECTION I

DESCRIPTION OF PROMINENT WASTE-TO-ENERGY PROCESSES

IDENTIFICATION OF RESEARCH NEEDS CONCERNING AIR POLLUTION ASPECTS OF WASTE-TO-ENERGY PROCESSES

REVIEW OF FACILITY OF SIGNIFICANT OPERATING AND RESEARCH FINDINGS 
ACKNOWLEDGEMENTS

This report was prepared for the Division of Environmental Control technology of the U.S. Department of Energy as part of Contract W-7405ENG-82 to Ames Laboratory (DOE) and Iowa State University, Ames, Iowa. The use of trade names does not indicate endorsement by the authors, Iowa State UnIversity, Ames Laboratory, or the U.S: Department of Energy. 


\section{LIST OF TABLES}

Table No.

Title

Page

1 "Refuse-derived fuel plants in the U.S. as of Nov. 1979 (11).

Mass-burning energy conversion facilities in the U.S. as of Nov. 1979 (11).

Large-scale pyrolysis systems in the U.S. as of Nov. 1979 (11).

Selected emissions from Boiler Unit 5 at Ames, Iowa when co-firing coal and RDF (17).

Selected emissions from Boiler Unit 6 at

Ames, Iowa when co-firing coal and RDF (17).

Selected emissions from Boiler Unit 7 at Ames, lowa when co-firing coal and RDF (19).

Unit conditions and particulate emissions at

Wisconsin Electric Power Plant when burning RDF (36).

Corrected field test results for four coal:dRDF

blends. Stoker-fired boiler at Hagestown, Maryland. (Emission data were normalized to the March

referenced coa1)(9).

Average heavy metal emissions in ash from blend firing tests of coal and densified RDF. Stokerfired boilers, Hagerstown, Maryland (9).

\section{LIST OF FIGURES}

Figure No.

1

2
Title

Page

Flow diagram of a solid waste processing plant designed to produce refusemderived fuel for energy recovery.

Schematic diagram of a typical mass burning solid waste processing/energy recovery plant.

Schematic diagram of a pyrolysis plant (Union Carbide's PUROXTM). 


\section{EXECUTIVE SUMMARY}

\section{INTRODUCTION}

Substantial public and private research effort recently has been invested in developing processes for converting municipal solid waste (MSW) to useable energy. The technology has progressed through demonstration phases into the designing, building and successful operation of full scale facilities that, in many cases, are providing economically attractive utilization of municipal solid waste. As fuel prices continue to increase, waste-to-energy conversion will become even more competitive with landfills as an economical and energyconserving waste disposal method. The potential then exists for increased use of waste-to-energy processes for disposal of MSW in closer proximity to urban sources of wastes.

The design and operation of much currently used air pollution equipment is based on the burning of fossil fuels and not municipal solid waste. It therefore follows that assessment of the ability of conventional air pollution control technology to meet current and proposed air quality standards at municipal waste-to-energy facilities is appropriate. Both the U.S. Environmental Protection Agency (EPA) and Department of Energy (DOE) made such assessments a priority early in their waste-to-energy programs. Much of this work was done with pilot or demonstration scale plants, or under less-than-ideal test conditions at "operating" facilities; and some recently developed and promising concepts, designs or operating alternatives have not been evaluated. Also it seems that a sufficient number of measurements may not have been made in previous tests to provide statistically valid data bases. This report presents the results of a survey of waste-to-energy facilities conducted: 
1. To produce an updated status report on capabilities of current air pollution control technology to meet existing and proposed air quality standards when municipal solid wastes are used as part or all of the energy input to a generating facility;

2. To identify significant findings in recent research and development projects that may suggest that air pollution control technology constraints may limit the feasibility of wide-spread use of municipal solid waste as an energy source; and

3. To identify additional air pollution control technology research and development needs associated with waste-to-energy conversion.

This report presents the results of this survey. Section I contains a brief general description of the three prominent types of waste-to-energy conversion processes in use at the present time, a brief history of federal government funded research on these processes, and a summary of significant research needs. Section II contains an update of the operating status and significant air pollution' control operating experiences and associated research findings for existing wasteto-energy conversion facilities on a case by case basis. 
CONCLUSIONS AND RECOMMENDATIONS

The observations and facts presented in this report point clearly to the need for a comprehensive program to conduct an industry-wide assessment of particulate, trace element, and hydrocarbon alr emission levels from each waste-to-energy process to provide a data base for decision making purposes. Research is needed to determine suitable methods for controlling particulate, gaseous and metals emissions from the three major types of waste-to-energy conversion processes so that environmental control and waste disposal policy makers will have adequate information to help make system choices. While a significant amount of research has been conducted concerning the capabilities of conventional air pollution control equipment to meet current and proposed air quality standards, unanswered questions still remain. Specific research and development needs are summarized as follows:

\section{General Research Needs Applicable}

to a11 Waste-to-Energy Systems

1. Documentation of trace metals emissions from waste-to-energy processes is sparce at best and is almost non-existent for organic materials. Thus further tests to quantify these parameters is needed. The limited data available, while not providing an adequate statistical base for drawing firm conclusions, do indicate the potential for hazardoue metals emissinns from some of the operating, full-scale waste-to-energy processes. U.S, EPA also recently has reported that findings of trace hazardous organic in stack gases from some of these processes definitely show the need for further investigation although certified documentation of these observations has not been published to date (12). 
2. Air pollution emissions from various waste-to-energy conversion processes now in operation should be compared on a common basis (ton for ton or BTU for BTU) including particulates, trace metals, chlorides (or HC1) and hazardous organics. This has not been done to date. Air pollution control processes with significant advantages should be identified. This survey should include processes co-firing conal. and RDF, indirert and direct heated pyrolysis units and conventinnal mass-incineration and fluidized-bed incineration processes.

3. Air emission investigations like those mentioned in 1 and 2 above should be extended to look at possible co-disposal of sewage sludge and hazardous wastes with MSW. Although there seems to be little published documentation of any such attempts at co-disposal especially involving hazardous industrial wastes, the potential may be significant. Any such emission work should include searching for emission products that may result from co-disposal that would not appear when burning the municipal solid waste separately or when co-firing MSW with coal or o11.

4. An overal1 system analyses of the environmental/economic/operational aspects of waste-to-energy conversion should be performed to provide a basis for selecting combinations of processing and air pollution control technologies which will optimize energy recovery efficiency and minimizc undesirable emissions.

5. Bacterial and viral emissions from the exhausts of dust control equipment used on front-end processes (grinding, screening, etc.) should be investigated and compared to emissions from other disposal sites such as landfills, sewage treatment processes, tran'sfer stations, 
animal feed lot or confinement buildings so that hazards specific to municipal solid waste processing can be tdentified.

\section{Specific Mass-Incineration Research Needed}

1. Methods are needed for controlling waste feed and excess air rates so that incinerator operating conditions can be adjusted to minimize particulate emissions and maximize the effectiveness of air pollution control equipment. For example, some modular combustion units use a two-stage combustion chamber to help reduce particulate emissions:

2. Trace element and chloride emissions from fluidized-bed incineration of MSW should be investigated to determine if this process has significantly reduced emissions as compared to conventional incinerations.

3. The following supplements to conventional incinerator air pollution control equipment should be investigated:

a. Addition of alkaline material to the refuse bed to promote binding of chloride into the bottom ash:

b. Partial recirculation of flue gas as a means of reducing emissions of particulate and nitrogen oxides.

\section{Specific Co-Firing Research Needs}

1. Tests should he extended to determine the effect of firing port placement on particulate emissions when co-firing coal and refusederived fuel (RDF) suspension-fired boilers, For example, at Ames, Iowa, RDF injection ports were placed below the coal firing ports and particulate standards were met; Wisconsin Electric placed the RDF ports above the coal ports and particulate emission standards were not met. 
2. Tests when co-firing coal and $\mathrm{RDF}$ should be conducted to determine the long-term effects on the performance of air pollution control equipment. Tests at Wisconsin Electric indicated detrimental long-term effects; but when RDF co-firing was stopped, the ESP performance returned to norma1 (36).

3. Tests should be conducted to investigate the effects of changes in the operation of stoker-fired boilers in organic emissions when cofiring $\mathrm{RDF}$, specifically, when $f l y$ ash reinjection is no longer practiced.

4. The potential for co-firing RDF in small stoker-fired boilers having mechanical collectors should be investigated further. Studies at Ames show that it may be feasible to meet current air quality standards with high efficiency cyclones if operating parameters are controlled properly and RDF processing is designed to minimize the amount of dust - and fines reaching the boiler.

5. Tests should be conducted to determine the relationship between frontend processing methodology and trace element and particulate emissions and boiler operating problems, such as slagging and ash handling.

6. Densified RDF ( $d-R D F)$ processing and co-firing with coal or oil should be investigated in detail to see if it has significant advantages over regular (fluff) RDF from an air pollution standpoint and to determine if costs can be reduced to a level competitive with $\mathrm{RDF}$ to take advantage of improved burnout, increased storage time characteristics, and burning without boiler modification. There is some evidence that co-firing $d-R D F$ with coal or oil improves the 
resistivity of ash for ESP collection purposes and may also cause some of the sulfur from fuel oil to be contained with the ash.

7. The effect of boiler heat release rate on particulate emissions when co-firing coal and RDF should be investigated.

8. The ability of fluidized-bed furnaces to tie up metals and to help minimize toxic metals emissions should be investigated.

\section{Specific Pyrolysis Research Needs}

1. The extent to which heavy metals and other potential pollutants are bound into the char or slag produced by pyrolysis should be determined. If significant binding is found, methods should be examined to exploit this phenomenon.

2. Gaseous emissions from pyrolysis processes should be examined to determine the potential for release of undesirable trace elements or hazardous organic materials.

3. Because fixed carbon in the char produced in some pyrolysis processes can comprise $18 \%$ by weight and $30 \%$ of the heat content of MSW (28), steps should be taken to develop methods for recovering thịs energy. Thcse melliuds thust be acceptable from an air pollution standpoint and also must be economically feasible. 
8

THIS PAGE

\section{WAS INTENTIONALLY}

LEFT BLANK 


\section{SECTION I}

\section{DESCRIPTION OF WASTE-TO-ENERGY PROCESSES}

Waste-to-energy conversion processes in full-scale operation or advanced demonstration stages in the U:S. can be divided into three major categories: co-combustion, mass incineration and pyrolysis. Co-combustion consists of 1) some combination of shredding, classifying or other "front-end" processing of MSW into a recycleable (heavy) fraction and a burnable (light) fraction known as refuse-derived fuel (RDF), and 2) firing of the RDF in combination with a fossil fuel in a conventional fossil fuel boiler modified for this purpose (Figure 1, Table 1). The "front-end" processing varies significantly from facility to facility with each producing an RDF having unique characteristics, such as particle size, that affect its endpoint use. This processing can be carried further to include densification of RDF into powder, granules or briquettes that are expected to have significantly improved storage qualities and can be mixed directly with coal or oil and fired in existing power plants without having to make extensive boiler modifications.

Mass incineration recovers energy from MSW by burning unprocessed waste in large, thermally efficient waterwall incinerators (Figure 2, Table 2). Most energy recovery incinerators are similar to coal-fired stoker generating units in that they employ moving grates for charging and ash removal. Waterwall boilers typically are used to recover flue gas heat and generate steam. Individual units may have a capacity in excess of 1000 TPD of MSW. There are a few other types of facilities in various stages of design, construction and operation which either shred or wet pulp MSW for use in fluildized bed, suspension-fired or stoker-fired boilers. 
AIR CLASSIFIER

\section{Cyclone Separator}

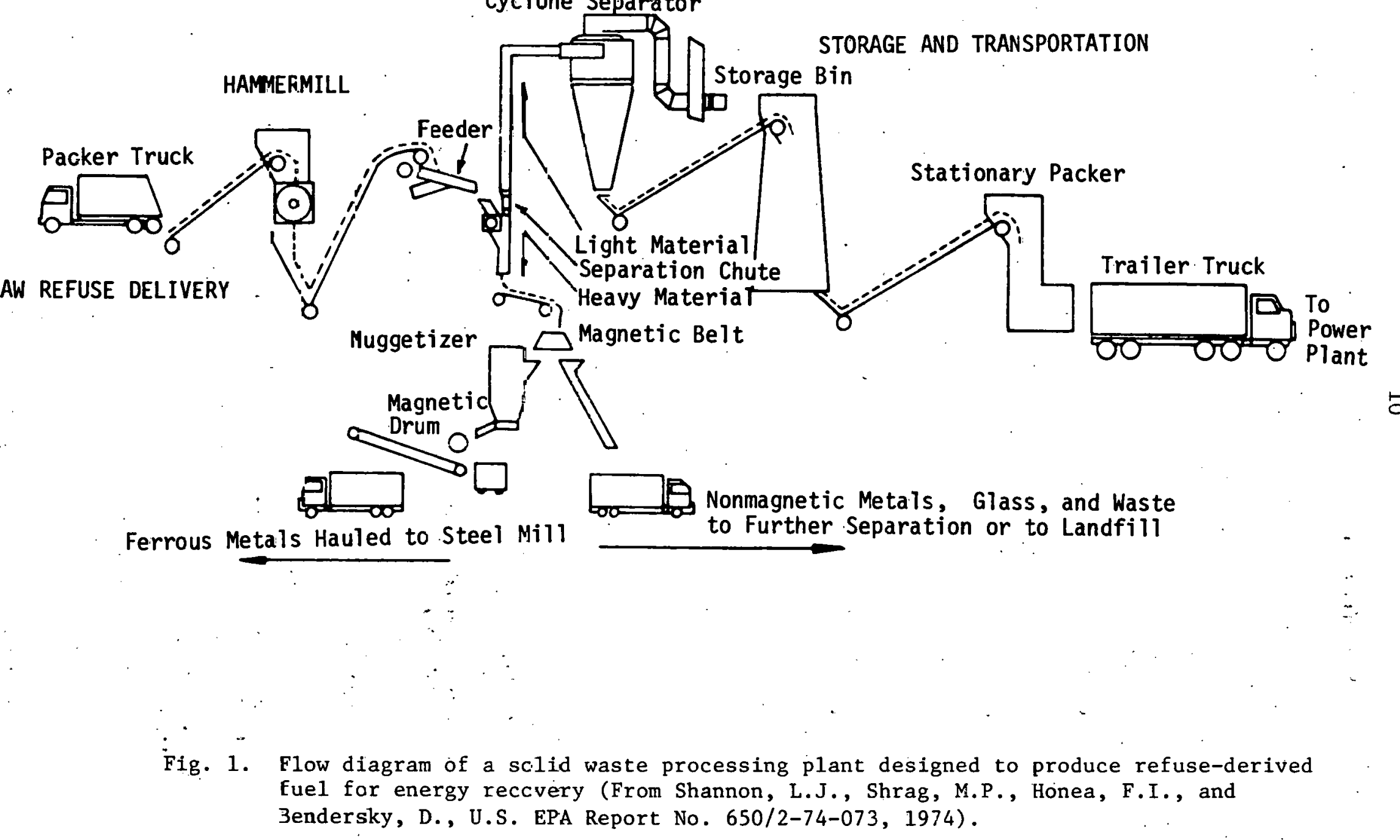


Table 1. Refuse-derived fuel plants in the U.S. as of Nov. 1979 (11).

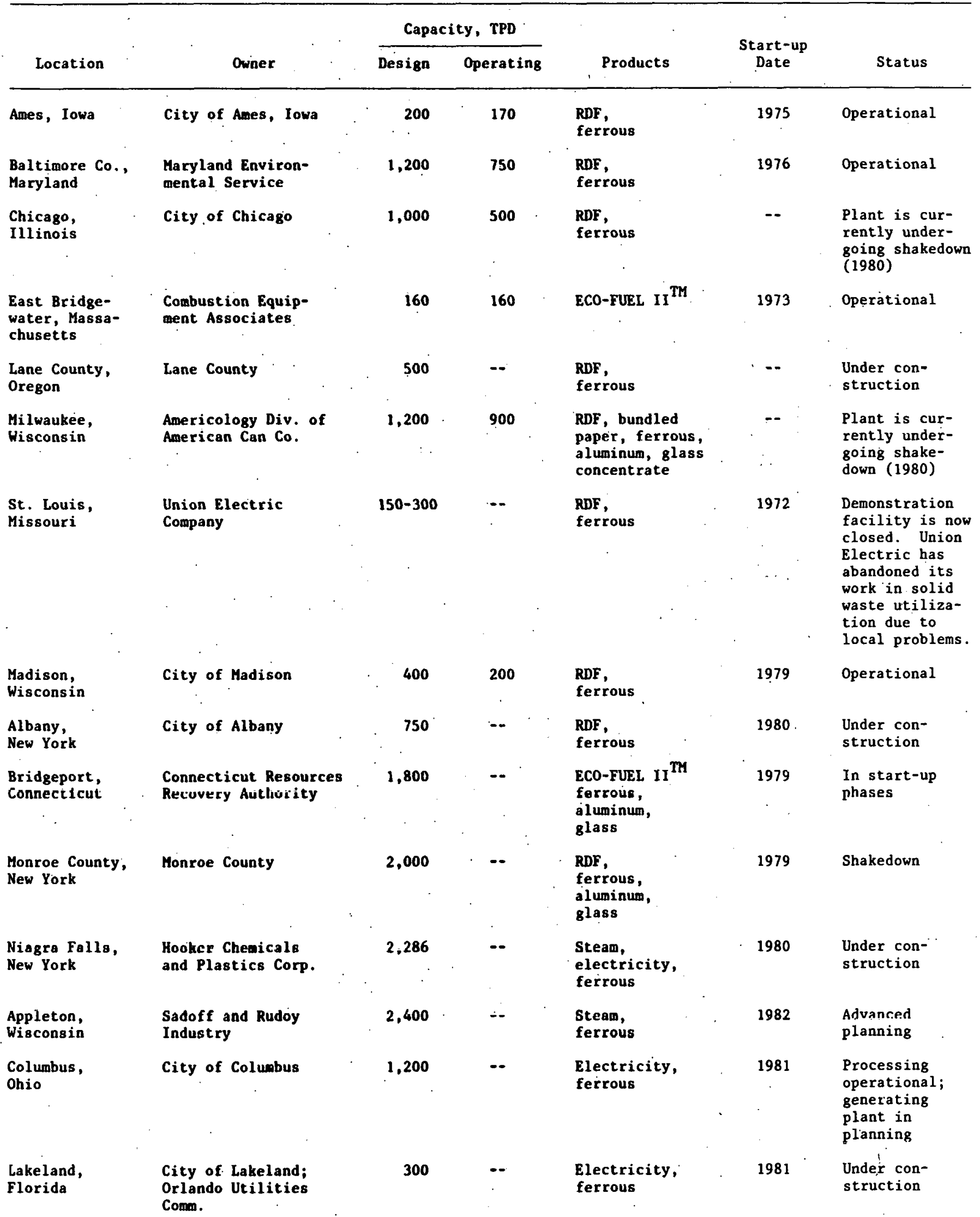


Table 1. Continued.

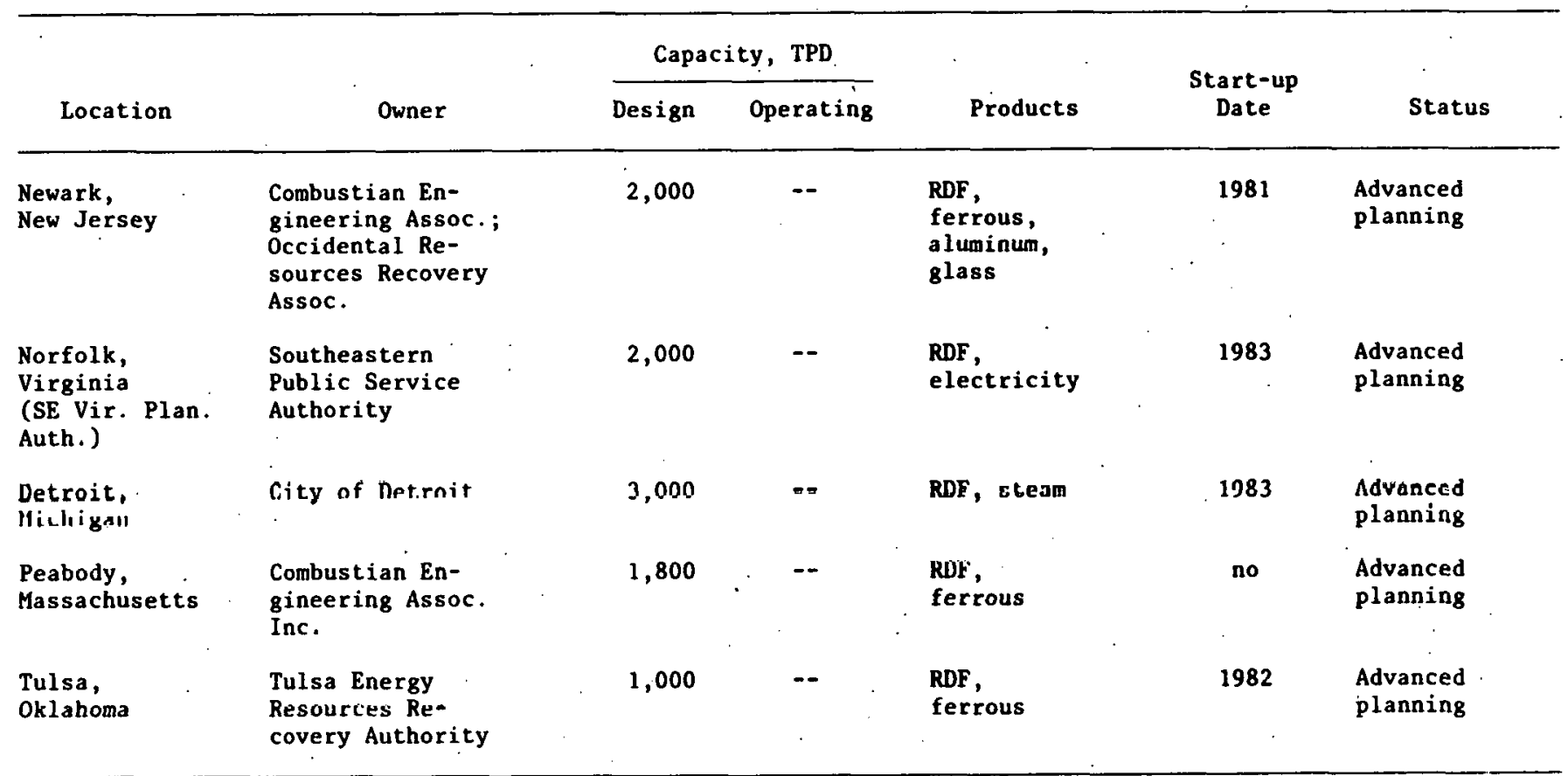




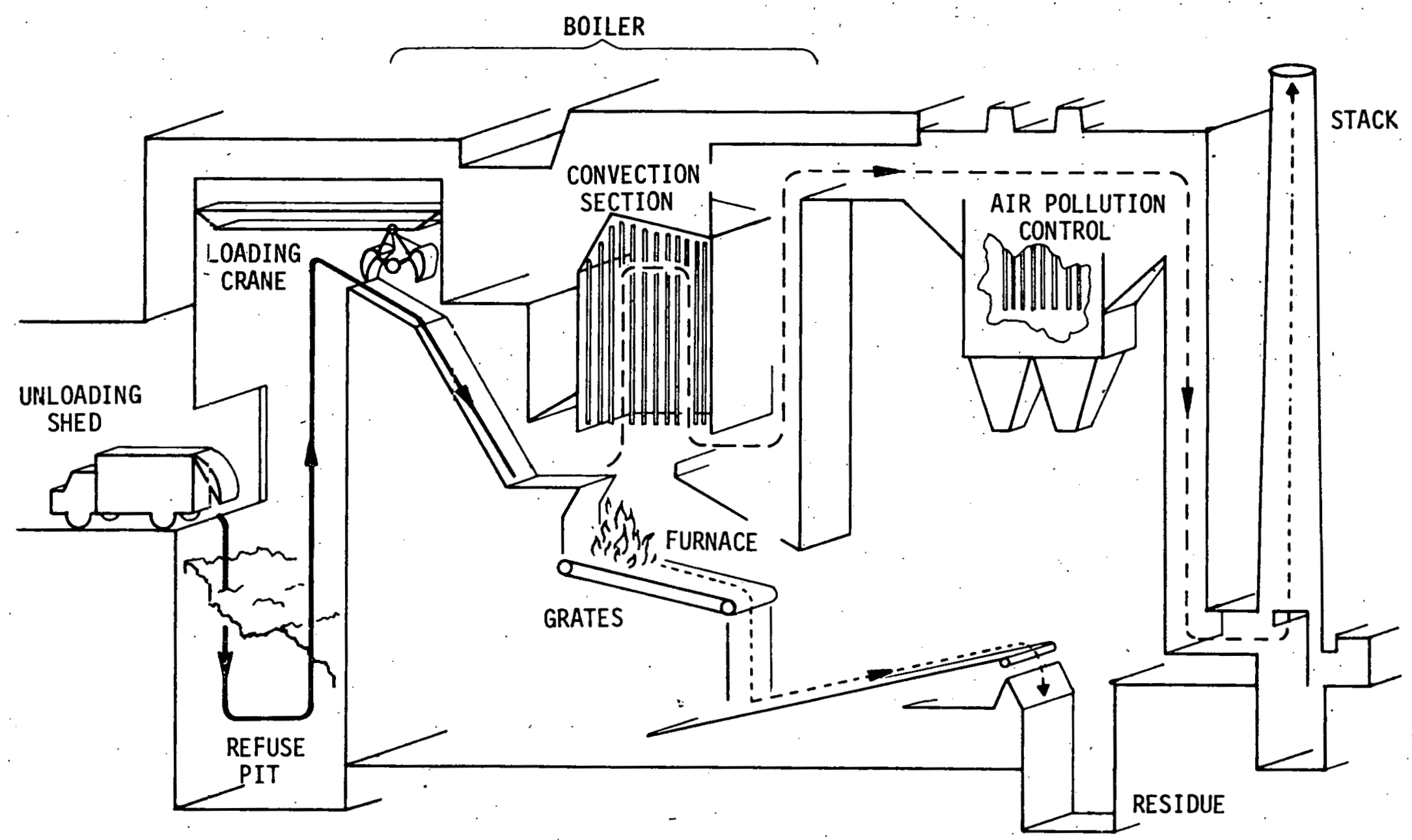

Fig. 2. Schematic diagram of a typical mass-burning solid waste processing/energy recovery plant (From Levy, S.J., Rigo, H.G., U.S. EPA Report No. SW-157.2, 1976). 
Table 2. Mass-burning energy conversion facilities in the U.S. as of Nov. 1979 (11).

\begin{tabular}{|c|c|c|c|c|c|c|}
\hline \multirow[b]{2}{*}{ Location } & \multirow[b]{2}{*}{ Owner } & \multicolumn{2}{|c|}{ Capacity, TPD } & & \multirow{2}{*}{$\begin{array}{l}\text { Start-up } \\
\text { Date }\end{array}$} & \multirow[b]{2}{*}{ Status } \\
\hline & & Design & Operating & Products & & \\
\hline $\begin{array}{l}\text { Braintree, } \\
\text { Massachusetts }\end{array}$ & $\begin{array}{l}\text { City of } \\
\text { Braintree }\end{array}$ & 384 & 250 & Steam & 1971 & Operational \\
\hline $\begin{array}{l}\text { City of } \\
\text { Chicago }\end{array}$ & $\begin{array}{l}\text { City of Chicago } \\
\text { (Northwest) }\end{array}$ & 1,600 & 1,200 & Steam & 1971 & Operational \\
\hline $\begin{array}{l}\text { Harrisbụrg, } \\
\text { Pennsylvania }\end{array}$ & $\begin{array}{l}\text { City of } \\
\text { Harrisburg }\end{array}$ & $\begin{array}{ll} & 720+ \\
14 & \text { sludge }\end{array}$ & 500 & Steam & $\begin{array}{c}1972 \\
(1979)\end{array}$ & Operational \\
\hline $\begin{array}{l}\text { Nashville, } \\
\text { Tennessee }\end{array}$ & $\begin{array}{l}\text { Nashvillc Thermal } \\
\text { Transfer Corp. }\end{array}$ & 720 & 400 & Sleam & 1974 & Operational \\
\hline $\begin{array}{l}\text { Norfolk, } \\
\text { Virginia }\end{array}$ & $\begin{array}{l}\text { U.S. Naval } \\
\text { Station }\end{array}$ & 360 & 140 & Steam & 1967 & Operational \\
\hline $\begin{array}{l}\text { Saugus, } \\
\text { Massachusetts }\end{array}$ & RESCO & 1,500 & 1,000 & $\begin{array}{l}\text { Steam, } \\
\text { ferrous }\end{array}$ & 1976 & Operational \\
\hline $\begin{array}{l}\text { Oceanside, } \\
\text { New York }\end{array}$ & $\begin{array}{l}\text { Township of } \\
\text { Hempstead, N.Y. }\end{array}$ & 750 & 750 & $\begin{array}{l}\text { Steam, } \\
\text { electricity }\end{array}$ & $\begin{array}{r}1974) \\
(1976)\end{array}$ & Operational \\
\hline $\begin{array}{l}\text { Portsmouth, } \\
\text { Virginia }\end{array}$ & $\begin{array}{l}\text { Norfolk Naval } \\
\text { Shipyard }\end{array}$ & 160 & 30 & Steam & 1976 & Operational \\
\hline Akron, Ohio & City of Akron & 1,000 & & $\begin{array}{l}\text { Steam, } \\
\text { ferrous }\end{array}$ & 1980 & $\begin{array}{l}\text { Shakedown early } \\
1980\end{array}$ \\
\hline $\begin{array}{l}\text { Hampton, } \\
\text { Virginia }\end{array}$ & NASA, USAF & 200 & & Steam & 1980 & $\begin{array}{l}\text { Expected start- } \\
\text { up latc } 1980\end{array}$ \\
\hline $\begin{array}{l}\text { Glen Cove. } \\
\text { New York }\end{array}$ & City of Glen Cove & $25 \begin{array}{l}225+ \\
\text { sludge }\end{array}$ & & Electricity & 1981 & $\begin{array}{l}\text { Under con = } \\
\text { struction i980 }\end{array}$ \\
\hline $\begin{array}{l}\text { Wilmington, } \\
\text { Delaware }\end{array}$ & $\begin{array}{l}\text { Delaware Solid } \\
\text { Waste Authority; } \\
\text { Ratheon Service Co. }\end{array}$ & $\begin{array}{c}1,000+ \\
50 \text { sludge }\end{array}$ & & Steam & $\dot{1982}$ & $\begin{array}{l}\text { Under con- } \\
\text { struction } 1980\end{array}$ \\
\hline $\begin{array}{l}\text { Dubuque, } \\
\text { Iowa }\end{array}$ & $\begin{array}{l}\text { Dubuque Metropoli- } \\
\text { tan Area Solid } \\
\text { Waste Agency }\end{array}$ & 250 & & $\begin{array}{l}\text { Steam, } \\
\text { ferrous }\end{array}$ & 1981 & $\begin{array}{l}\text { Under con- } \\
\text { struction. }\end{array}$ \\
\hline $\begin{array}{l}\text { Gallatin, } \\
\text { Tennessee }\end{array}$ & $\begin{array}{l}\text { Gallatin, Hender- } \\
\text { sonville, Summer } \\
\text { Count.y. Alithority }\end{array}$ & $\cdot 150$ & & $\begin{array}{l}\text { Steam, } \\
\text { electricity }\end{array}$ & 1981 & $\begin{array}{l}\text { Advanced } \\
\text { planning }\end{array}$ \\
\hline $\begin{array}{l}\text { Nim } 1 \text { l, Antouves, } \\
\text { Massachusetts }\end{array}$ & $\begin{array}{l}\text { Universal uil } \\
\text { Products, Inc. }\end{array}$ & 3,000 & . & Elect ${ }_{\text {Licity }}$ & $\mathrm{ND}$ & $\begin{array}{l}\text { Advanced } \\
\text { planning }\end{array}$ \\
\hline $\begin{array}{l}\text { Beverly, } \\
\text { Massachusetts }\end{array}$ & $\begin{array}{l}\text { Industrial Devel- } \\
\text { opment Financing } \\
\text { Authority }\end{array}$ & 591 & & $\begin{array}{l}\text { Steam, } \\
\text { electricity }\end{array}$ & $\mathrm{ND}$ & $\begin{array}{l}\text { Advanced } \\
\text { planning }\end{array}$ \\
\hline $\begin{array}{l}\text { Pinalles } \\
\text { County, Florida }\end{array}$ & Pinellas County & 2,000 & & $\begin{array}{l}\text { Electricity, } \\
\text { ferrous, non- } \\
\text { ferrous }\end{array}$ & 1982 & $\begin{array}{l}\text { Advanced } \\
\text { planning }\end{array}$ \\
\hline $\begin{array}{l}\text { Westchester } \\
\text { County, N.Y. }\end{array}$ & $\begin{array}{l}\text { Contractor and } \\
\text { Municipal Authority }\end{array}$ & 1,500 & & Steam & 1983 & $\begin{array}{l}\text { Advanced } \\
\text { planning. }\end{array}$ \\
\hline
\end{tabular}


Pyrolysis involves the thermal-chemical decomposition of waste under controlled pressure, temperature and residence time by indirect application of heat. Ideally, the only gas flow leaving a pyrolysis reactor is that resulting directly from the decomposition of the waste from the solid to the gaseous phase (and of course those gases introduced when charging wastes such as through an air lock feeder). The type and consistency of the product (gas, liquid or char) produced from a heterogenous waste such as MSW is dependent on exposing all of the waste to the desired design temperature, pressure and residence time. Accomplishing pyrolysis in an essentially sealed reaction vessel through indirect heating is relatively simple compared to attempting to control combustion of a heterogenous waste in systems using large quantities of excess air such as those designed for combustion of coal.

Pyrolysis processes differ in reactor designs, operating temperatures and reactor temperature gradients, residence times, recovered fuel characteristics and carrier gas source and composition (if any). Most full-scale pyrolysis systems that have been demonstrated to date have been starved-air combustion units in which part of the waste is burned in one section of the reactor to produce heat to Necompose the remaining organic material (F1gure 3, Table 3). Only the PYRO-SOL process has adhered to the use of indirect heating and exposure of all the input feedstock to a fixed residence time and temperature (33). Some such as the Baltimore facility, have on-site secondary combustion chambers with energy recovery in the form of steam or steam generated electricity only. Process residues range from inert slag to carbon-rich chars. 


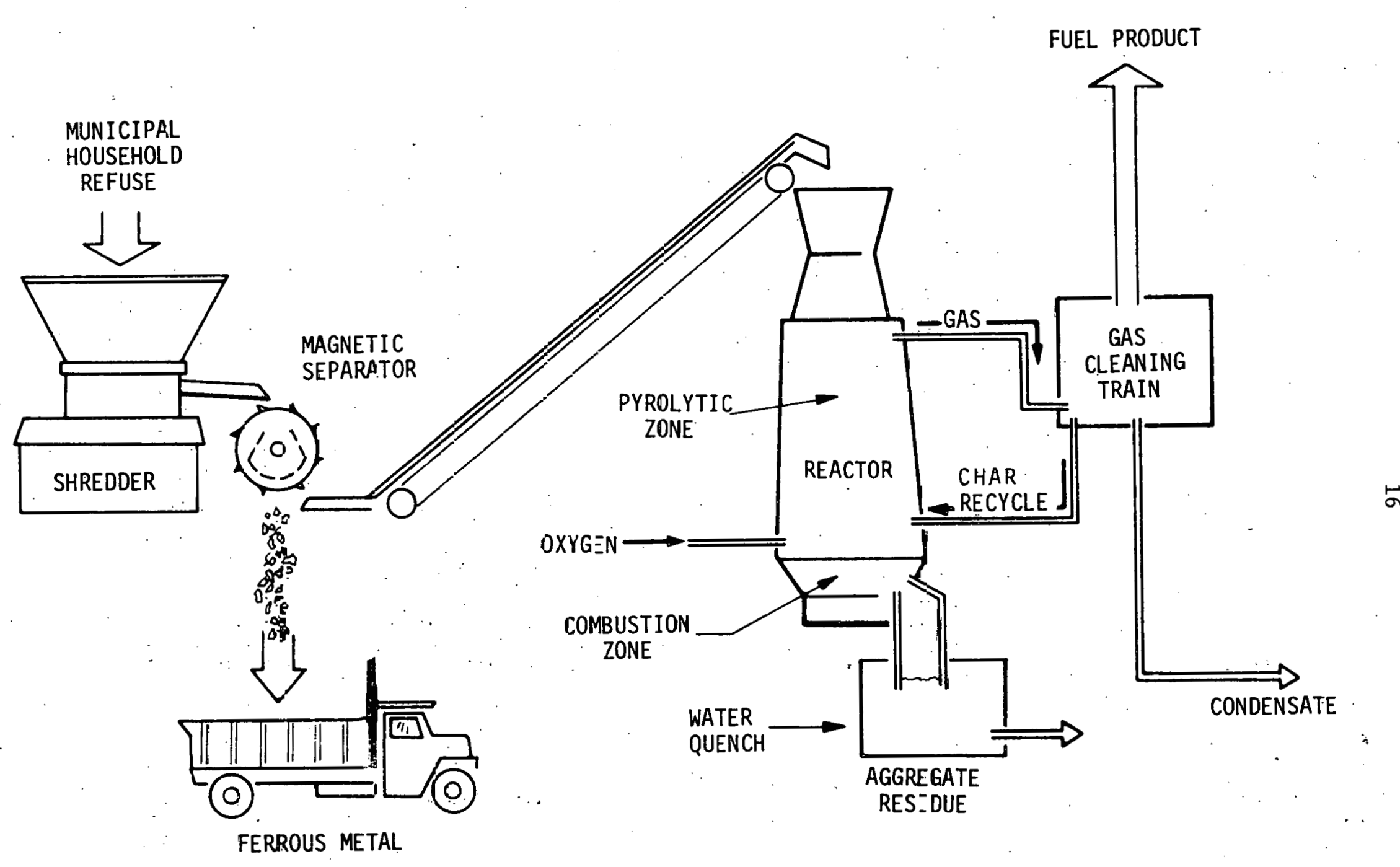

Fig. 3. Schematic diagram of a pyralysis plant (Union Carbide's PUROX ${ }^{\mathrm{TM}}$ ). (From Report on Status of Technology in the recovery of Resources from Solid Wastes, County Sanitation Eistricts of Los Angeles, CA, January, 1979) 
Table 3. Large-scale pyrclysis systems in the U.S. as of Nov. 1979 (11).

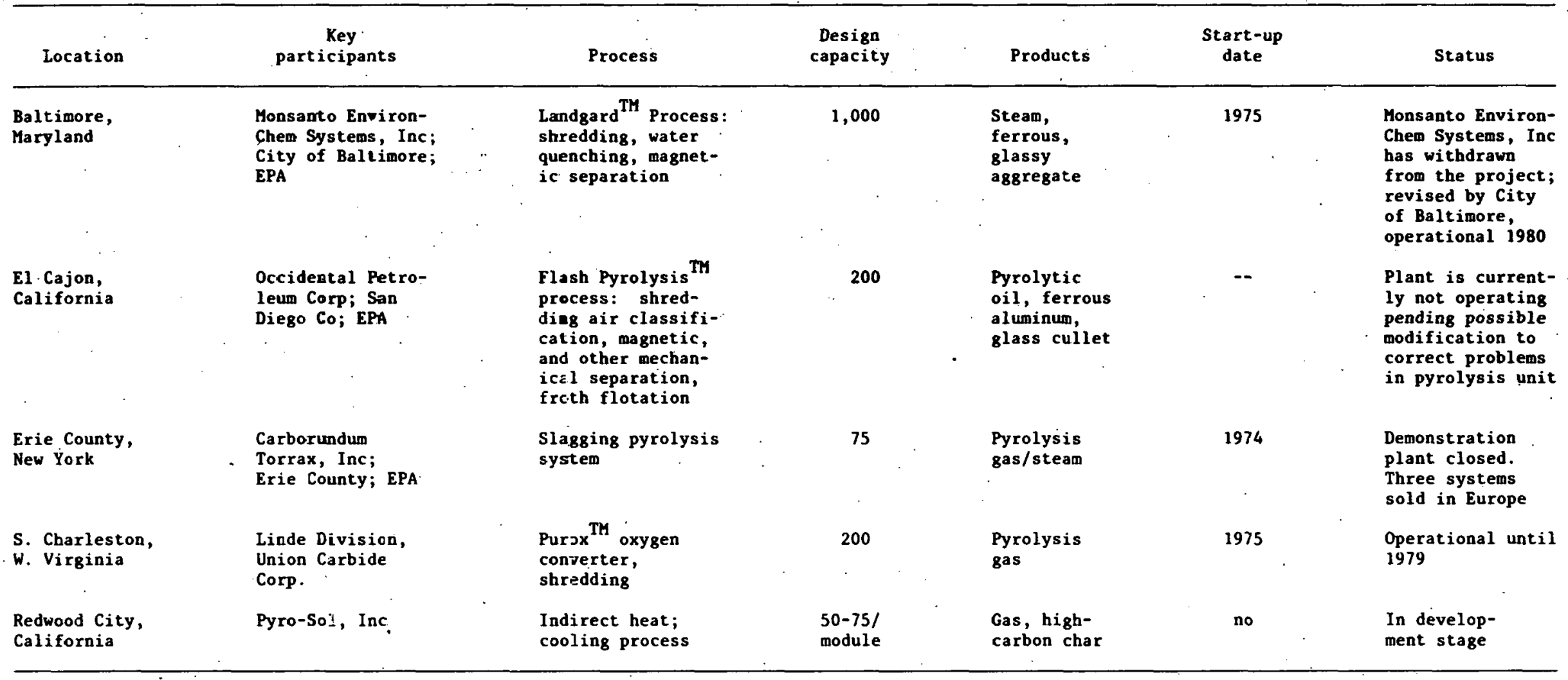


18

THIS PAGE

WAS INTENTIONALLY

LEFT BLANK 


\section{SECTION II}

IDENTIFICATION OF RESEARCH NEEDS CONCERNING THE

AIR POLLUTION ASPECTS OF WASTE-TO-ENERGY PROCESSES

In 1974 EPA's Municipal Environmental Research Laboratory (MERL) required, as part of the City of St. Louis - Union Electric co-combustion demonstration project, a study of air pollution control efficiencies and emissions as well as a limited look at bacterial and viral emissions from front-end processing (1). Since then, EPA's Industrial Environmental Research Laboratory (IERL) has included air pollution emission studies as part of almost all waste-to-energy demonstration projects in which it has taken part. Of these, the investigation of the Ames Solid Waste Recovery System in Ames, Iowa is especially noteworthy because of its comprehensive nature. The Department of Energy, EPA and others have cooperated over a three year period to study emissions while co-firing RDF and coal in both stokerand suspension-fired coal utility boilers at Ames. This investigation included an evaluation of the effects of various boiler modifications and RDF characteristic changes on air pollution control equipment operating performance as weil as on emisoions $(17,19)$.

IERL also has taken broader looks at air pollution control at waste-to-energy conversion facilities in three other studies. Their "Engineering and Economic Analysis of Waste-to-Energy Systems" published in May of 1978, included an evaluation of the air pollution control aspects of some eight waste-to-energy installations (35). EPA also has contracted with Midwest Research Institute of Kansas City to conduct an "Environmental Assessment of Waste-to-Energy Processes" (13). Third, PEDCO Environmental of Cincinatt, Ohio has published "A1r Pollution Emissions and Control Technology for Waste-As-Fue1 Piocesses" in October 1979 (10) as the initial effort in an EPA/IERL contract to develop, test, and evaluate pilot-scale air pollution control devices for use on various waste-to-energy processes.. Their 
report details the status of knowledge about air emissions from waste-to-energy processes and control equipment capabilities as of 1979 but did not identify research needs.

These and other reports have concluded that not enough reliable data are available to adequately assess the air pollution impacts of mass incineration for other than particulates. If this is true it follows that it would be difficult to provide any kind of comprehensive comparisons of the air pollution impaces of the various waste-to-energy processes. But in spite of this conclusion, there are some indications in the literature and from current research projects that there may indeed be significant differences in these impacts and in air pollution control equipment capabilities to meet air quality standards. For example, Greenberg, Zoller and Gordon from the University of Maryland (15) concluded after studying composition and gize of particles released in refuse incineration in 1978 that "If all urban refuse were burned in inrineratore, the level of some toxic elements in urban air would probably be intolerah. e." These include $\mathrm{Cd}, \mathrm{Sn}, \mathrm{Ag}, \mathrm{Pb}$ and possibly vapor-phase mcrcury. Granted, this does not account for cooler exhaust streams from mass-burning energy recovery which likely causes some condensation with subsequent removal in particulate collection devices. However, the PEDCO (10) report references studies which show that a large portion of metals are adsorbed onto the large surface areas of the smaller particle fractions (less than 2 micrometers) which leads to the probab1lity that large amounts of metals (75\% or greater of $\mathrm{Pb}, \mathrm{Zn}, \mathrm{Cd}, \mathrm{Cu}$ and others) escape collection by air pullucion control devices. It is this size range that is most likely to be inhaled deep into the lungs, thus making their removal more important. 
There are only limited available data on the differences in trace metal emissions between firing coal only and coal plus RDF. The PEDCo report (10) concludes (pg. 135) that control of lead on fine particles from co-firing may be necessary. This conclusion is based on their comparison of conservatively estimated ground level concentrations with work-place threshold limit values established by OSHA as being safe for continuous 40 hours a week exposure. EPA has not yet formally addressed heavy metals emissions from coal firing, and any required control would likely apply both to mass incineration and to co-firing of municipal solid wastes.

Indirect-heated pyrolysis (such as used in the PYRO-SOL process) appears to be unique among waste-to-energy systems in its potential for control of the type and consistency of the products leaving the reaction vessel with similar implications for quality of energy production and for environmental control. DOE's Resource Recovery Research, Development and Demonstration plan (pgs. 194196) draws similar conclusions (28). The processes developed by Union Carbide $\left(\right.$ PUROX $^{\text {TM }}$ ) Monsanto (LANDGARD), ANDCO Inc. (ANDCO-TORRAX) or Occidental Research Corp. (Flash Pyrolysis) all introduce either air or pure oxygen into the pyrolysis chamber for combustion of part of the waste to provide sufficlent heat to pyrolyze the remainder. This causes the pyrolytic gases to be diluted with combustion products and nitrogen. The resulting product gas stream is larger in volume, more contaminated with solids and high molecular weight Uiganic matcriale, less cnnsistent in quality and lower in BTU content than that produced by indirectly heated pyrolysis (References 6, 25, $29 \& 34$ provide good examples of the types of pilot scale pyrolysis processes that have been developed for disposing of wastes). 
Currently there is practically no trace element emission information available for any of the pyrolysis processes. Union Carbide, though not currently operating its PUROX ${ }^{\mathrm{TM}}$ plant, claims low trace element emission upon combustion of their produce gas, but substantial trace elements remain in their wastewater sludges (24). Andco-Torrax claims a $40 \%$ reduction of flue gas flow over waterwall incineration. But with potentially incomplctc pyrolysis and without gas cleaning prior to the secondary rombustivil vlumber, metals emission may be a problem. PYRO-SOL, the only operational indirect-heated pyrolysis system has shown very low particulate emissions from combustion of product gas in a boiler without control equipment. Metals and complex organic emissions also are expected to be very low because of long residence time at pyrolysis design temperatures and low temperature product gas recovery which also provides extensive gas cleaning (32).

Western Europe turned heavily to mass incineration in the 1970's and currently disposes of the wastes of some 100 million penple in thic way much of it employs energy recovery (22). But since then many of these countries are showing concern for emissions from these incinerators. West Germany for example, will require chloride control on any new incinerators (8). Many of the RDF emission studies have shown significant increases in sh1nride omiceion over coal alone $(9,17,19)$.

Recent attempts by EPA to lower incinerator particulate emission standards from 0.08 to $0.03 \mathrm{gr} / \mathrm{SCF}$ has brought a flurry of comments on supposed difficulties for current ESP control technology to maintain a $0.03 \mathrm{gr} / \mathrm{SCF}$ standard over the years (2). This could be another indication that more municipalities and MSW disposal firms are considering mass incineration-energy recovery as refuse transportation costs increase. 


\section{REVIEW BY FACILITY OF SIGNIFICANT OPERATING EXPERIENCE AND RESEARCH FINDINGS}

A brief description of the significant operating experiences and research findings as reported in the above referenced reports and as learned from dis-. cussions with designers or operating personnel are included here for currently operating waste-to-energy facilities. This review is presented by facility type: co-combustion, mass incineration, then pyrolysis.

\section{Co-combustion Facilities}

Ames Solid Waste Recovery System - Ames, Iowa

The Ames Solid Waste Recovery System (19) consists of one resource recovery RDF production line currently processing 100 to 150 tons per day (TPD) of MSWW via 2-stage shredding, ferrous metal removal, and air classification. The RDF is stored in a 500 ton capacity Atlas storage bin and is fired in any of three boilers, two of which are small spreader stokers ( 7.5 or $12.5 \mathrm{MW}$ ) and the other a larger (35 MW) suspension fired unit.

Boiler operation evaluation while co-firing RDF. Evaluation of the Ames boiler operation resulted in the following conclusions:

Existing stoker-fired boilers:

1. Boiler grate heat release design rate (BTU's/hr/f.t of grate) and geometry of flue gas routing may affect particulate loadings at the entrance to the air pollution control unit (20).

2. Introducing overfire air from the front of the boiler seems to have the effect of increasing residence time of combustibles thereby promoting more complete burning and consequent decrease in particulate loadings. 
3. Elimination of the fines re-injection (recycling of a portion of the fly ash from some collection point back to the boiler) may very well reduce particulate loadings at the expense of a slight decrease in boiler efficiency.

4. Appropriate coal screening reduces the amount of coal fines and seems to result in decreased particulate emissions. This action will make it easier to meet particulate standards when co-firing RDF and coal.

5. Some combination of the above changes in buller operation may make it possible to use existing smaller stoker-flred boilers without modification or with more efficient mechanical collectors (such as cyclones and baghouses) which cannot be used currently because they will not meet particulate standards for firing coal or coal plus RDF; and their size will not justify installation of expensive ESP's. This is exactly the case for Ames Units $5 \& 6$ where new mechanical collectors and reduction of $\mathrm{RDF}$ fines has made it possible to meet particuate standards. Similar changes may make it economically feasible to burn RDF in 10cations where stokers already exist but which cannot justify additional capital investments as required for mass-burning or large suspensionfired boilers,

Existing suspension fired boilers: It was found in the Ames co-firing tesls that the lucdtion of the $\mathrm{RDF}$ injection-firing ports relative to the coal ports influenced both the stack emission and the amount of unburned RDF dropping into the bottom ash hopper (19). Moving the RDF injection ports to a location below coal injection and retrofiting a dump grate into the bottom of the boiler have solved the problem of unburned wastes and minimized the impact of $\mathrm{RDF}$ firing on stack emissions. Boiler heat release rate design criteria also 
may affect particulate emissions when burning RDF, but such a correlation has not yet been verified (20):

Changes in RDF processing: Reducing fines in RDF by as much as $50 \%$ significantly decreases slagging problems because of the increased ash softening temperature. Ash content also is reduced by as much as $50 \%$ (19). This lower ash content also will reduce particulate loadings into the APC equipment. This conclusion applies to stoker-fired as well as suspension-fired units.

Emission tests evaluation: Emission tests on the spreader-stoker boilers at Ames while co-firing RDF with coal (Tables $4 \& 5$ ) show significant increases in chlorides and trace elements lead, copper and zinc in the fine particulates above the levels normally found when firing coal alone (17). These tests were run in 1976 and 1977. In September of 1979 additional particulate tests for compliance purposes were run on one boiler (No. 6) after the installation of new, higher efficiency mechanical dust collectors while burning low-ash Culorado coal and RDF processed to remove fines and to lower the ash content. The tests were conducted at average $70 \%$ of rated boiler 1 ad and $40 \% \mathrm{RDF}$ by heat content. The associated particulete emioeions averaged 0.412 1b/MBTU. This shows a substantial improvement over the 1976-77 tests during which 2 to 4.4 1b/MBTU particles were measured (17). Even though these tests should not be compared strictly with the 76-77 data because of coal and operating condition differences, it is obvious that the experiences and equipment modifications at Ames have significantly reduced particulate emissions.

These decreases in particulate emissions probably will not significantly change gaseous chloride emissions but may change the trace metal emission rate from that reported in the 1976-77 tests since many metals are adsorbed to 
Table 4. Selected emissions from Boiler Unit 5 at Ames, Iowa when co-firing coal and RDF (17).

\begin{tabular}{|c|c|c|c|c|c|c|c|c|c|c|c|c|c|}
\hline \multirow[b]{2}{*}{ Parameter (units) } & & \multicolumn{3}{|c|}{$\begin{array}{l}80 \% \text { load } \\
1976 \text { Iowa } \\
\text { coal with }\end{array}$} & \multicolumn{3}{|c|}{$\begin{array}{l}80 \% \text { load } 1977 \\
\text { Iowa/Wyoming } \\
\text { coal with }\end{array}$} & \multicolumn{3}{|c|}{$\begin{array}{l}60 \% \text { load } \\
1976 \text { Iowa } \\
\text { coal with } \\
\end{array}$} & \multicolumn{3}{|c|}{$\begin{array}{l}100 \% \text { load } \\
1976 \text { Iowa } \\
\text { coal with }\end{array}$} \\
\hline & & $\begin{array}{l}0 \% \\
\text { RDF }\end{array}$ & $\begin{array}{l}20 \% \\
\mathrm{RDF}\end{array}$ & $\begin{array}{l}50 \% \\
\text { RDF }\end{array}$ & $\begin{array}{c}0 \% \\
\text { RDF }\end{array}$ & $\begin{array}{l}20 \% \\
\text { RDF }\end{array}$ & $\begin{array}{l}50 \% \\
\text { RDF }\end{array}$ & $\begin{array}{l}0 \% \\
\text { RDF }\end{array}$ & $\begin{array}{l}20 \% \\
\mathrm{RDF}\end{array}$ & $\begin{array}{l}50 \% \\
\mathrm{RDF}\end{array}$ & $\begin{array}{c}0 \% \\
\mathrm{RDF}\end{array}$ & $\begin{array}{l}20 \% \\
\mathrm{RDF}\end{array}$ & $\begin{array}{l}50 \% \\
\mathrm{RDF}^{\mathrm{a}}\end{array}$ \\
\hline Particulates (ccntrolled) & $(\mathrm{g} / \mathrm{MJ})$ & 0.7 & 0.4 & 0.3 & 0.8 & 0.9 & 1.0 & 0.9 & 1.1 & 1.3 & 1.3 & 0.4 & 0.4 \\
\hline Particulates (uncontrollea) & $(g / M J)$ & 3.6 & 4.1 & 3.4 & 3.2 & 3.8 & 4.2 & 3.2 & 4.4 & 3.5 & 4.1 & 2.2 & 3.1 \\
\hline Oxides of sulfur, $\mathrm{SO}_{\mathrm{x}}$ & $(\mathrm{g} / \mathrm{MJ})$ & 2.3 & 1.9 & 1.5 & 1.0 & 0.7 & 0.9 & 1.3 & 2.3 & 0.8 & 2.4 & 2.0 & 1.7 \\
\hline Oxides of nitrogen, $\mathrm{NO}_{\mathbf{x}}$ & (mg/MJ) & 80.0 & 76.0 & $\epsilon 4.0$ & 77.0 & 67.0 & 69.0 & 99.0 & 104.0 & 78.0 & 81.0 & 76.0 & 50.0 \\
\hline Chlorides & (mg/MJ) & 13.0 & 68.0 & 97.0 & 6.5 & 87.01 & 139.0 & 22.0 & 58.01 & 100.0 & 7.0 & 62.01 & 101.0 \\
\hline Formaldehyde & $\left(\mathrm{mg} / \mathrm{ML}^{-}\right)$ & 0.2 & 0.2 & 4.3 & 11.7 & 3.7 & 3.4 & 2.7 & 3.1 & 6.2 & 3.3 & 2.0 & 0.2 \\
\hline Hydrocarbons & $(\mathrm{mg} / \mathrm{MJ})$ & 0.22 & 0.17 & 0.19 & 0.08 & 0.09 & 0.07 & 0.15 & 0.19 & 0.31 & 0.09 & 0.15 & 0.17 \\
\hline
\end{tabular}

${ }^{a}$ Only two runs at this load and \% RDF were accomplished. 
Table 5. Selected emisstons from Boiler Unit 6 at Ames, Iowa when co-firing coal and RDF (17).

\begin{tabular}{|c|c|c|c|c|c|c|c|c|c|}
\hline \multirow[b]{3}{*}{ Parameter (units) } & & \multicolumn{3}{|c|}{$80 \%$ load } & \multicolumn{2}{|c|}{$80 \%$ load } & \multicolumn{3}{|c|}{$60 \%$ load } \\
\hline & & \multicolumn{3}{|c|}{$\begin{array}{l}1976 \text { Iowa/Wyoming } \\
\text { coal with }\end{array}$} & \multicolumn{2}{|c|}{$\begin{array}{l}1977 \text { Iowa/Wyoming } \\
\text { coal with }\end{array}$} & \multicolumn{3}{|c|}{$\begin{array}{l}\text { 1977 Iowa/Wyoming } \\
\text { coal with }\end{array}$} \\
\hline & & $0 \%$ RDF & $20 \% \mathrm{RDF}$ & $50 \% \mathrm{RDF}$ & $0 \% \mathrm{RDF}^{\mathrm{a}}$ & $50 \% \mathrm{RDF}$ & $0 \% \operatorname{RDF}$ & $20 \% \mathrm{RDF}$ & $50 \% \mathrm{RDF}$ \\
\hline Part1culates (controlled) & $(g / M J)$ & 0.5 & 0.7 & 0.9 & 0.8 & 1.9 & 0.7 & i.8 & 1.7 \\
\hline Particulates (uncontrolled) & $(g / M J)$ & 2.5 & 3.5 & 4.4 & 1.8 & 3.9 & 2.0 & 3.7 & 4.3 \\
\hline Oxides of sulfur, $\mathrm{SO}_{\mathrm{x}}$ & $(g / M j)$ & 0.8 & 0.3 & 0.4 & 0.9 & 0.6 & 1.4 & 0.8 & 0.5 \\
\hline Oxides of nitrogen, ${ }^{\mathrm{NO}} \mathrm{x}_{\mathrm{x}}$ & $(\mathrm{mg} / \mathrm{MJ})$ & 133.10 & 131.0 & 106.0 & 91.0 & 88.0 & 106.0 & 52.0 & 96.0 \\
\hline Chlorides & $(\mathrm{mg} / \mathrm{MJ})$ & 6.3 & 44.0 & 88.0 & 9.4 & 110.0 & 4.2 & 96.0 & 127.0 \\
\hline Formaldehyde & (mg/MJ) & 5.8 & 0.6 & 1.6 & 16.0 & 20.0 & 22.0 & 28.0 & 23.0 \\
\hline Hydrocarbons & (mg/MJ) & -- & -- & -- & 0.07 & 0.13 & 0.08 & 0.07 & 0.07 \\
\hline
\end{tabular}

${ }^{a}$ Only two runs at this load and \% RDF were accomplished. 
particulates that pass through the APC device.

Stack emissions data obtained from the suspension fired boiler at Ames (Unit 7) while burning RDF are summarized in Table 6.(19). Additional compliance tests run in September 1978 after changing the RDF firing port location from above the coal nozzles to below them indicate further improvement in particulate emissions beyond that experienced by dump grate installation. Chloride emissions increased with increasing percent $R D F$ in a manner simflar to that found in the stoker-fired Units 5 and 6 (Table 6). Additional tests run at 16 to $18 \%$ RDF content (by BTU) and $100 \%$ load showed a decrease in particulates from 0.57 1b/MBTU before moving the RDF injection port to $0.31 \mathrm{lb} / \mathrm{MBTU}$ after lowering the injection port (32). Madison Gas and Electric - Madison, Wisconsin

The City of Madison, Wisconsin processes MSW to produce RDF for firlng. by Madison Gas and Electric in a 50 MW suspension-fired pulverized coal boiler. The air pollution control device at this plant is an ex1sting electrostatic precipitator that was conservatively designed for use with low-sulfur western coal. Although as of this writing comprehensive emission tests have not been performed, preliminary observations indicate that ESP performance is excellent when burning RDF. This entire operation has proven so succeeoful that Madison Gas and Electric is finalizing plans to similarly modify a second 50 MW suspension fired unit for firing RDF sometime during 1980 (5). It is logical that the ESP here would be more likely to perform well when burning RDF (assuming good solid waste burnout) because low sulfur coal has fly ash resistivity characteristice closer to RDF fly ash than does high sulfur coal. Therefore, any ESP designed to perform well with low sulfur fly ash would be expected to perform well with RDF fly ash. There is also belief among some researchers that expected heat 
Table 6. Selected emissions from Boiler Uritt 7 at Ames, Iowa, when co-firing coal and RDF (19).

\begin{tabular}{|c|c|c|c|c|c|c|c|c|c|c|c|c|}
\hline \multirow[b]{3}{*}{ Parameter } & \multicolumn{6}{|c|}{$\begin{array}{l}\text { Prior to Installation of } \\
\text { Dump Grates } 1976,1977\end{array}$} & \multicolumn{6}{|c|}{ After Installation of Drump Grates 1978} \\
\hline & & & \multirow{2}{*}{$\frac{\text { Load }}{\mathrm{RDF}}$} & \multirow{2}{*}{$\frac{80 \% \text { Load }}{0 \% \mathrm{RDF}}$} & \multicolumn{2}{|c|}{$100 \%$ Load } & \multicolumn{3}{|c|}{$80 \%$ Load } & \multicolumn{3}{|c|}{$100 \%$ Load } \\
\hline & & & & & $0 \% \mathrm{RDF}$ & $10 \% \mathrm{RDF}$ & $0 \% \mathrm{RDF}$ & $10 \% \mathrm{RDF}$ & $20 \% \mathrm{RDF}$ & $0 \% \mathrm{RDF}$ & $10 \% \mathrm{RDF}$ & $20 \% \mathrm{RDF}$ \\
\hline $\begin{array}{l}\text { Particulates } \\
\quad \text { (controlled) }\end{array}$ & $\mathrm{Ib} / 10^{6}$ & $\mathrm{BTU}^{\mathrm{a}}$ & 0.23 & 0.35 & 0.60 & 0.53 & 0.21 & 0.37 & 0.37 & 0.42 & 0.44 & 0.53 \\
\hline $\begin{array}{l}\text { Particulates } \\
\quad \text { (urcontrolled) }\end{array}$ & $1 b / 10^{6}$ & BTU & 9.05 & 7.49 & 8.26 & 8.35 & 6.54 & 7.63 & 8.21 & 7.93 & 7.28 & 7.47 \\
\hline $\begin{array}{l}\text { Oxides of } \\
\text { Sulfur } \mathrm{SO}_{\mathrm{x}}\end{array}$ & $1 b / 10^{6}$ & $\mathrm{BTE}^{-}$ & 2.61 & 2.88 & 3.70 & 2.88 & 3.42 & 2.84 & 2.33 & 3.30 & 2.33 & 1.93 \\
\hline $\begin{array}{l}\text { Oxides of } \\
\text { Ni=rogen } \mathrm{NO}_{\mathrm{x}}\end{array}$ & $1 b / 10^{6}$ & BTU & 0.32 & 0.26 & 0.35 & 0.27 & 0.39 & 0.33 & 0.33 & 0.31 & 0.26 & 0.26 \\
\hline Chlorides & $1 b / 10^{9}$ & BTD & 5.14 & 13.6 & 28.14 & 7.65 & 10.7 & 50.9 & $93.7^{\circ}$ & 7.65 & 58.4 & 28.6 \\
\hline Formaldehyde & $1 \mathrm{~b} / 10^{9}$ & BTU & 4.56 & 20.9 & 5.49 & 60.0 & 8.37 & 12.0 & 0.77 & 0.19 & 1.44 & 0.42 \\
\hline Methane & $1 \mathrm{~b} / 10^{9}$ & BTJ & 0.00 & 0.00 & 0.00 & 0.00 & 5.30 & 6.07 & 3.77 & 3.35 & 4.58 & 2.47 \\
\hline
\end{tabular}


release rates (BTU transfer per square foot) used in boiler design may be critical to good RDF burnout and that the Madison unit is an example of a boiler design well-suited to burning RDF (20).

Milwaukee, American Can, Wisconsin Electrical RDF Co-combustion

The City of Milwaukee, the Americology Division of the American Can. Co. and Wisconsin Electric Power are cooperating in an effort to produce RDF for use by Wisconsin Electric in supplementing suspension firing of coal in their Oak Creek plant units 7 and 8 (310 MW each). These are among the largest boilers ever used to fire RDF. Some boiler slagging and low ESP efficiency problems have been experienced during 2 years of extensive testing and evaluation by Wisconsin Electric (Table 7). There is some indication that the experience gained at Ames in experimenting with 1) RDF firing port locations on their suspension fired boiler and 2) RDF fines content could possibly solve some of the problems at Milwaukee, From on air emissions standpoint, ESP's on both boilers would not meet paiticulate emission standards of 0.15 h/MBTU whil buritig RUF. Also emission rates seem to increase with accumulative RDF fired. ESP performance returned to normal overnight after co-firing of RDF was stopped (36).

Chicago Supplementary Fuel Processing Plant and Commonwealth Edisuil Cu-Combustion

The City of Chicago and Commonwealth Edison are cooperating in a joint venture to corvert MSW to RDF for co-combustion in utility boilers at the Commonwealth Edison Crawford plant adjacent to the processing facility. The City of Chlcago has built what is one of the larger capac1ty RUF (1000 TPD) production plants currently in existence (35). The process includes primary shredding, air classification into heavy and light fractions with resource recovery or landfilling of the heavy fraction, and secondary shredding of the light fraction. The 
Table 7. Unit conditions and particulate emissions at Wisconsin Electric Power Plant when burning RDF (36).

\begin{tabular}{|c|c|c|c|c|c|}
\hline $\begin{array}{l}\text { Test } \\
\text { No. }\end{array}$ & $\begin{array}{l}\text { Test } \\
\text { Date }\end{array}$ & $\begin{array}{l}\text { Steam Load } \\
(\mathrm{k} 1 \mathrm{~b} / \mathrm{hr})\end{array}$ & $\begin{array}{l}\text { RDF Feed } \\
\text { (ton } / \mathrm{hr})\end{array}$ & $\begin{array}{c}\text { Particulate } \\
\text { Emissions } \\
\text { (1b/MBTU) }\end{array}$ & Unusual Conditions \\
\hline 1 & $5 / 18 / 79$ & - & - & - & Invalid-improper sampling technique. \\
\hline 2 & $5 / 18 / 79$ & 1677 & 0 & 0.159 & \\
\hline 3 & $5 / 21 / 79$ & - & - & - & Invalid-improper sampling technique. \\
\hline 4 & $5 / 21 / 79$ & 1802 & 0 & 0.172 & \\
\hline 5 & $5 / 22 / 79$ & 1775 & 0 & 0.242 & . \\
\hline 6 & $5 / 22 / 79$ & 1719 & 0 & 0.228 & \\
\hline 7 & $5 / 23 / 79$ & 1690 & 0 & 0.342 & $\begin{array}{l}\text { Precipitator double powered; power } \\
\text { supplies limited by arcinga }\end{array}$ \\
\hline 8 & $5 / 23 / 79$ & 1882 & 0 & 0.137 &.$" \quad$. \\
\hline 9 & $5 / 24 / 79$ & 1726 & 0 & 0.058 & Precipitator double powered. \\
\hline 10 & $5 / 24 / 79$ & 1841 & 0 & 0.047 & $"$ \\
\hline 11 & $5 / 25 / 79$ & 1758 & 0 & 0.050 & $"$ \\
\hline 12 & $5 / 25 / 79$ & 1666 & 0 & 0.036 & ". \\
\hline 13 & $5 / 31 / 79$ & 1557 & 30 & 0.066 & $"$ \\
\hline 14 & $5 / 31 / 79$ & 1542 & 30 & 0.068 & $"$ \\
\hline 15 & $6 / 5 / 79$ & 1658 & 30 & 0.186 & : \\
\hline 16 & $6 / 5 / 79$ & 1602 & 30 & 0.196 & \\
\hline 17 & $6 / 7 / 79$ & 1596 & 21 & 0.390 & \\
\hline 18 & $6 / 8 / 79$ & 1594 & 20 & 1.442 & Excessive pulverizer fineness. \\
\hline 19 & $6 / 8 / 79$ & 1566 & 10 & 1.282 & $"$ \\
\hline 20 & $6 / 18 / 79$ & 1591 & 20 & 0.736 & \\
\hline 21 & $6 / 18 / 79$ & 1547 & 20 & 0.658 & . \\
\hline 22 & $6 / 19 / 79$ & 1554 & 10 & 0.566 & . \\
\hline 23 & $6 / 1.9 / 79$ & 1514 & 10 & 0.448 & \\
\hline 24 & $8 / 7 / 79$ & 1533 & 0 & 0.960 & $\begin{array}{l}\text { Test interrupred due to oyctem } \\
\text { requirements. }\end{array}$ \\
\hline 25 & $8 / 22 / 79$ & 1522 & 0 & 0.378 & \\
\hline 26 & $8 / 22 / 79$ & 1613 & 0 & 0.374 & . \\
\hline 27 & $8 / 23 / 79$ & 1209 & 0 & 0.094 & \\
\hline 28 & $8 / 24 / 79$ & 1146 & 0 & 0.278 & \\
\hline
\end{tabular}

${ }^{a}$ rcing was in the temporary double power connections, external to the precipitator. 
resultant RDF is transfered pneumatically to storage at the power plant for eventual co-combustion. Because the processing and co-combustion systems were designed in the early 70's, this facility did not benefit from improvements in processing and co-combustion designs developed in the last few years. The facility is currently (June 1980) shut down for equipment modifications and very little information is yet available ahnut power plant particulate emissions when co-firing RDF. Again, it may be that cxperiellec galned at Ames in improving burnout and decreasing ash content of RDF will lead to significant improvements in air pollution control.

\section{Densified RDF Co-combustion}

With the exception of the ECO-FUEL II process marketed by Combustion Equipment Associates (CEA) there has been only minor effort put into investigating processes for densifying RDF and turning it into a powdered, pelletized nr briquetted fuel for co-firing without modification to existing coal or oil-fired boilers or fuel-handling equipment.

Dust in the ECO-FUEL II production process is controlled with conventiona1. baghouse technology added after the facility was first constructed. Some sulfur is added to the fuel in the chemical imbrittlement stage of the process to make the fuel brittle so that heated ball mills call be used to accomplish final size reduction (ball mills tumble small heated steel bills through the waste). The aulfur cuntent specillcarion of the fuel is $0.6 \mathrm{lb} / \mathrm{million}$ BTU heat input (7). Currently, ECO-FUEL II from CEA's ECO FUEL processing plant at Bridgeport, Connecticut is being co-fired with oil in a boiler located at United Illuminating Co. State particulate standards are being met, but meeting the Connecticut sulfur standard of $0.55 \mathrm{lb}$ S/MBTU heat input is still in question. CEA claims 
an overall process energy efficiency equivalent to coarse size reduction only and the use of ECO-FUEL II is expected to require little or no boiler modification. EPA has contracted with Systems Technology Corporation (SYSTECH) of Xenia, Ohio to evaluate boiler performance and emissions while burning 285 tons of densified RDF briquettes (1/2" diam. x 3/4" long) in two small stoker-fired boilers $(60,000$ $1 \mathrm{~b} / \mathrm{HR}$ and $75,000 \mathrm{lb} / \mathrm{HR}$ steam) at Hagerstown, MD. The report evaluating the tests of these boilers is in draft form (9) as of August 1980. The preliminary results from the Hagerstown tests did not indicate any significant boiler operating problems while burning briquette/coal blends although low steam demands prevented testing at full boller loads. Briquettes were successfully fired at $100 \%$ of the boiler fuel during this evaluation but resulted in the clogging of bottom ash handing equipment.

Emissions tests showed 1) no significant increase in particulate emissions above coal alone (Table 8), 2) an increase in chloride emissions (Table 8), and 3) an increase in some metals and a decrease in others (Table 9). These results only indicate trends because they were observed during very low boiler load conditions and when using only low-efficiency cyclones for fly ash collection.

The data analysis is not yet completed for the second larger boiler tested by SYSTECH at Erie, Pennsylvania using densified RDF briquettes in a 150,000 1b/HR spreader-stoker steam boiler at which particulate emissions are controlled by an ESP. Also, in 1978 Detroit Edison evaluated the grinding and handling properties of a single, several hundred ton, batch of briquettes produced from ECO-FUEL II but an apparent mistake in briquette producion caused serious briquette deterioration, dust problems and equipment clogging and prevented continuous firing. This precluded any meaningful evaluation of boiler performance or emissions (31). 
Table 8. Corrected fleld test results for four coal:dRDF blends.

Stoker-fired boller at Hagerstown, Maryland.

(Emission data were normalized to the March referenced coa1)(9).

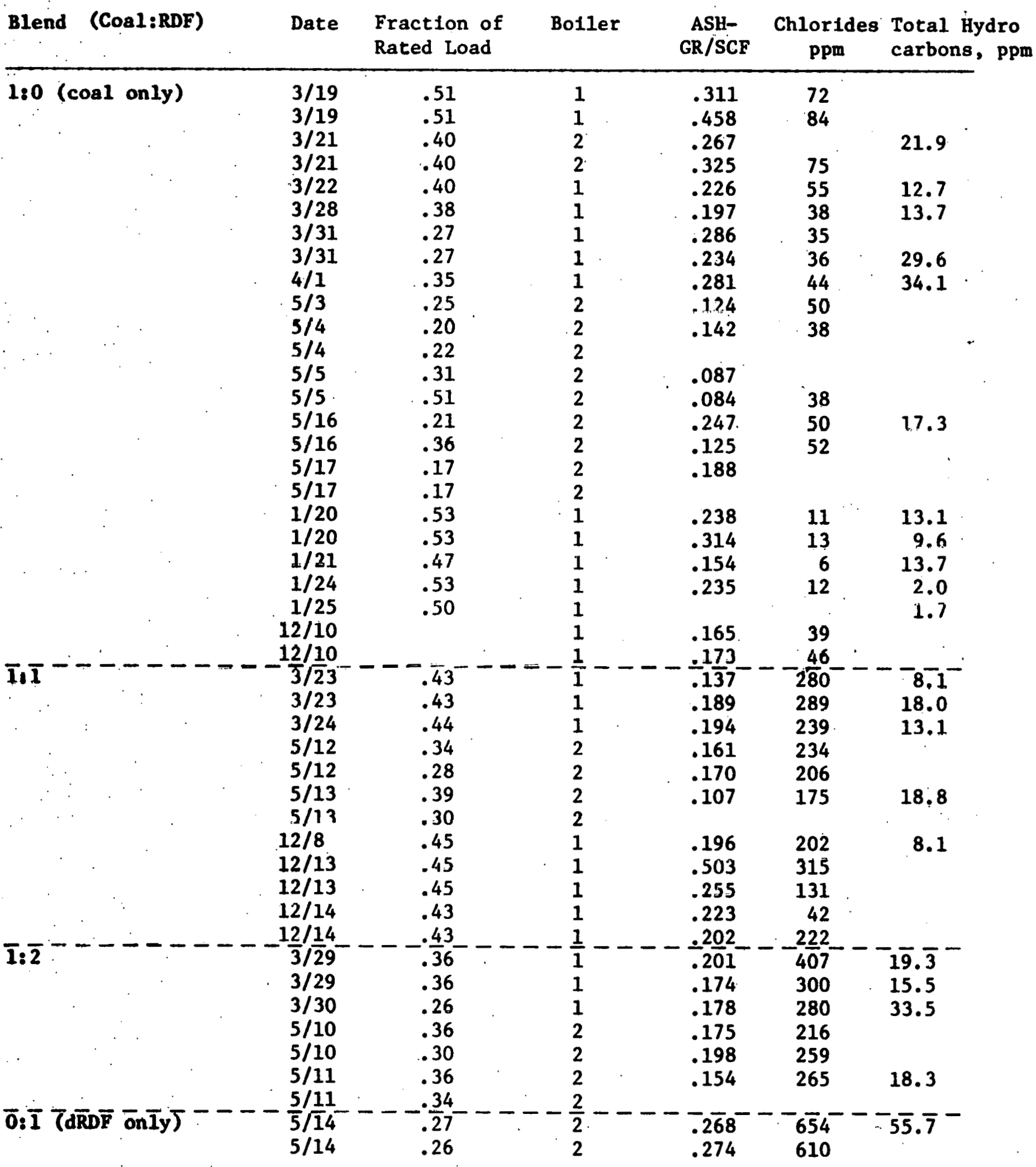


Table 9. Average heavy metal emissions in stack particulates from blend firing tests of coal and densified RDF in stoker-fired boilers at-Hagestown, Maryland (9).

\begin{tabular}{|c|c|c|c|c|c|c|c|c|c|c|c|c|c|c|c|c|c|}
\hline \multirow[b]{2}{*}{ MONTH } & & & \multirow{2}{*}{$\begin{array}{l}\text { Coal: } \\
\text { RDF } \\
\text { Blend }\end{array}$} & \multirow{2}{*}{$\begin{array}{l}\text { No. of } \\
\text { samples } \\
\text { analyzed }\end{array}$} & \multicolumn{2}{|r|}{$\cdots$} & \multicolumn{2}{|l|}{ ' } & \multicolumn{3}{|c|}{ Metals } & \multirow[b]{2}{*}{$\mathrm{Zn}$} & \multirow[b]{2}{*}{$\mathrm{Cu}$} & \multirow[b]{2}{*}{ Sn } & \multirow[b]{2}{*}{ Sb } & \multirow[b]{2}{*}{$\mathrm{Ag}$} & \multirow[b]{2}{*}{ Vn } \\
\hline & & & & & $\mathrm{Pb}$ & $\mathrm{Cd}$ & As & $\mathrm{Hg}$ & $\mathrm{Cr}$ & $\mathrm{Ni}$ & Mn & & & & & & \\
\hline . & . & $\therefore$ & $\therefore$ & $\bar{\vdots}$ & & $\therefore$ & $\therefore$ & & Thresh & old $1 i$ & imit $1 \mathrm{e}$ & e1, i & $\mathrm{\mu g} / \mathrm{m}^{3}$ & & .9 & , & \\
\hline . & & . & & . & 200 & 20 & 500 & 100 & 100 & 1000 & -- & 5000 & -- & - & 500 & 10 & . \\
\hline . : & $\cdots$ & & $\therefore$ & 5 & . & $\dot{.}$ & $\therefore$ & $\therefore$ & & & . & & & & & & \\
\hline MARCH & & & . & 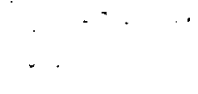 & . & & & & & & & & & & & & \\
\hline$\because$ & & - & $\begin{array}{l}1: 0 \\
1: 1 \\
1: 2\end{array}$ & $\begin{array}{l}7 \\
3 \\
3\end{array}$ & $\begin{array}{r}228 \\
3975 \\
7660\end{array}$ & $\begin{array}{l}\frac{<4.43}{79.4} \\
233\end{array}$ & $\begin{array}{r}173 \\
45.9 \\
44.9\end{array}$ & $\begin{array}{l}<7.85 \\
19.6 \\
12.3\end{array}$ & $\begin{array}{l}35.1 \\
33.5 \\
47.6\end{array}$ & $\begin{array}{l}32.6 \\
32.1 \\
41.0\end{array}$ & $\begin{array}{l}47.7 \\
64.6 \\
101\end{array}$ & $\begin{array}{r}592 \\
6012 \\
8569\end{array}$ & $\begin{array}{r}\leq 51.7 \\
96.1 \\
82.5\end{array}$ & $\begin{array}{r}\leq 1.46 \\
3.36 \\
4.99\end{array}$ & $\begin{array}{l}<87.2 \\
<52.2 \\
\leq 87.3\end{array}$ & $\begin{array}{l}<8.72 \\
12.0 \\
17.1\end{array}$ & $\begin{array}{r}<87.2 \\
<52.2 \\
59.6\end{array}$ \\
\hline MAY & & & & . & & & & & & & & & & & & & \\
\hline . & & . & $\begin{array}{l}1: 0 \\
1: 1 \\
1: 2 \\
0: 1\end{array}$ & $\begin{array}{l}7 \\
3 \\
3 \\
2\end{array}$ & $\begin{array}{r}230 \\
4237 \\
8217 \\
9953\end{array}$ & $\begin{array}{c}4.33 \\
7.2 .4 \\
220 \\
267\end{array}$ & $\begin{array}{r}184 \\
153 \\
126 \\
49.4\end{array}$ & $\begin{array}{l}<5.57 \\
15.7 \\
11.4 \\
94.7\end{array}$ & $\begin{array}{l}50.7 \\
35.4 \\
55.4 \\
79.7\end{array}$ & $\begin{array}{l}49.5 \\
35.9 \\
50.9 \\
29.4\end{array}$ & $\begin{array}{l}30.4 \\
62.6 \\
115 \\
275\end{array}$ & $\begin{array}{r}596 \\
5664 \\
8317 \\
8033\end{array}$ & $\begin{array}{c}50.1 \\
82.4 \\
134 \\
203\end{array}$ & $\begin{array}{r}<1.45 \\
2.70 \\
3.47 \\
6.07\end{array}$ & $\begin{array}{r}<65.6 \\
<48.5 \\
59.1 \\
<107\end{array}$ & $\begin{array}{l}<6.56 \\
<6.51 \\
19.4 \\
29.7\end{array}$ & $\begin{array}{l}<65.6 \\
<<8.5 \\
<59.1 \\
<107\end{array}$ \\
\hline
\end{tabular}


CEA claims (18) that the best approach to controlling hazardous metals emissions from solid waste-to-energy processes is to remove as many of the metals as practical in the front-end resource recovery process and then to produce a fuel with consistent burning characteristics that will eliminate hot spots and minimize incomplete combustion. In spite of efforts to remove all metals, lead emissions are still expected and may come frnm printing ink on Lhe paper in MSW (32). A mass balanced of metals in ECO-FIFI II cumbustion has not'yet been performed. CEA also expects that hlending a conoigteil puwdered kuf with coal or oil will improve burnout of the coal or oil (lowers the carbon content) and therefore will improve fly ash resistivity for electrostatic collection purposes. $\underline{\text { RDF Processing In-Plant Air Quality Control }}$

Essentially all RDF processing facilities that include any kind of shredding also include some type of in-plant dust collection system which generally is : extended throughout the processing line. These systems collect dust from shredding operations, exhaust from air classification and pneumatic conveying as well as at other interim processing points. Baghouses generally are used as control devices because of their reliability and efficiency in meeting particulate emission standarls. Bacterial and viral emissions from baghouse exhausts external to the building are not thought to be a problem (3) although only limited tests to verify this have been performed. Also, fines from these collectors may contain significant bacterial contamination but this has not been investigated. Current practice is often to burn them with the RDF.

Hempstead Resource Recovery Corp., Hempstead, New York

This private corporation built and operates a resource recovery system which is designed to take up to $2000 \mathrm{TPD} \mathrm{MSW}$ and produce RDF, through a wet-pulping 
process, which is then fired alone in an air-swept spout spreader stoker boiler. Dust control equipment is used to control air quality within the front-end processing building. ESP air pollution control is used on the boiler stack and has been tested at $0.032 \mathrm{gr} / \mathrm{std} \mathrm{ft}^{3}$ (26) which is about $30 \%$ of the New York State particulate standard. Emissions data other than particulates were not available at the time of this writing but EPA has conducted other tests which will be published in the near future.

\section{Mass-Incineration}

\section{RESCO (Refuse Energy System Co.). Saugus, Massachusetts}

The system at Saugus consists of two 7.50 TPD Von Roll waterwall incinerators of European design that have been operated for $3-1 / 2$ years at approximately their design capacity. Recent overhaul and grate replacement in the incinerators will raise total capacity to as much as 2000 TPD total MSW processed. Emission tests on the ESP's used for particulate control after a recent routine overhaul averaged $0.027 \mathrm{gr} / \mathrm{std} \mathrm{ft}^{3}$ as compared to a $0.05 \mathrm{gr} / \mathrm{std} \mathrm{ft}^{3}$ standard established by the State of Massachusetts (23). Incinerator residue is put through magnetic separation and is thèn sold as aggregate for use in road construction.

Nashvilie - Thermal Transfer Corp.

Thermal Transfer Corp. of Nashville operates two reciprocating grate waterwall incinerators rated at 360 TPD each. Original air pollution control equipment consisted of multicones and wet scrubbers. Emissions from these units did not meet air pollution standards of $0.08 \mathrm{gr} / \mathrm{std} \mathrm{ft}^{3}$ and these control devices were replaced with ESP's, one on each boiler unit (35). In addition to improved particulate collection efficiency, the increased draft also improved solid waste 
burnout. Since installation of the two ESP's, this waterwall incineration facility has operated very successfully with minimum manpower requirements, has met state standards for particulate emissions, and has had few operating problems after initial shakedown.

\section{Pyrolysis Waste-to-Energy Systems}

PUROX ${ }^{\mathrm{TM}}$ Syst.em

The PUROX ${ }^{\text {TM }}$ pyrolysis system was developed by the Union Carbide Corp. and was successfully operated at a 200 TPD level for procoooing a cumblnation of MSW and sewage sludge at South Charleston, West Virginia (24). The feedstock, consisting of shredded MSW with metals removed or a combination of processed MSW and partially dewatered sewage sludge, is injected near the top of a vertical reactor which has a counter-flow of hot gases (See Figure 3). The feedstock is dried in the upper section of the reactor, then descends further into a pyrolysis zone where breakdown of the cellulose produces gases, liquids and char. Pure oxygen is introduced at the bottom of the reactor to support the pyrolysis reactiun. Fyrulysis products include 1) molten inorganic släg which is quenched and 2) gases which rise through the descending refuse column. The gaseo leave the reactor at the top to be cleaned of oils, liquids, moisture and particulates in a wet-scrubbing/ESP system. Afterwards, it can be used or sold as a mediumvalue BTU gas. Energy conversion is equivalent to mass incineration but net efflelency (including front-end processing) is only about 50\% (35).

The gas cleaning system reduces the gas temperature to about $100^{\circ} \mathrm{F}$ which likely condenses most vaporized metalo. This condensation, in combination with front-end metals removal, reduces trace metal emissions resulting from final project gas combustion to very low levels (25). Co-disposal of sewage sludge in 
the PUROX ${ }^{\text {TM }}$ system results in a wastewater sludge having substantially reduced metals content when compared to conventional domestic wastewater sludge. The reason for this according to Union Carbide's mass balance information is that the majority of the metals in the feedstock are tied up in the inorganic inert silica slag taken off the bottom of the reactor.

Based on particulate loads in the product gas, Union Carbide estimates that particulate emissions from gas combustion after ESP control will be on the order of 0.001 to $0.003 \mathrm{gr} / \mathrm{SCF}$ at $12 \% \mathrm{CO}_{2}$ with trace metals emissions at correspondingly low levels in the stack (24). The PUROX ${ }^{\mathrm{TM}}$ System has baghouse dust control on the front-end typical of other shredding, classification and resource recovery sy.stems.

ANDCO-TORRAX Pyrolysis System

The. ANDCO-TORRAX system uses unprocessed MSW as feedstock in a vertical pyrolysis reactor similar in operational characteristics to the PUROX ${ }^{\text {TM }}$ system except that preheated air rather than pure oxygen is used to support the reaction. Consequently, the heating value of the pyrolysis gas is too low to justify cleaning and resale. Instead, it is burned immediately in a secondary combustion chamber using minimum excess air. A portion (10\%) of the exhaust gases are used to meet pyrolysis reactor preheat needs through use of regenerative heating towers and the remainder is used to produce steam in a heat recovery boiler (35). Conversion and net efflciencies arc Eimilar to those experienced for the PUROX ${ }^{\text {TM }}$ process. Ihe use of a secondary combustinn chamber instead of a product gas cleaning system eliminates any significant wastewater stream, but the lack of front-end metals recovery and low temperature product gas cleaning before final gas cumbustion mcans increased potential for trace metals emissions in the air 
pollution stream relative to the PUROX ${ }^{\mathrm{TM}}$ system. However, compared to conventional mass incineration installations of similar size, ANDCO-TORRAX claims (ton for ton of MSW) approximately $40 \%$ less exhaust gas volume (30). Therefore, it is expected to produce at least $40 \%$ lower emissions per ton of refuse disposed than mass incineration with equivalent air pollution control equipment. This does not take into account any differences in tie-up of metals in inert slag versus incinerator residue. Like PUROX ${ }^{\text {TM }}$, the TORRAX system also produces an inert slag which is usable as concrete aggregate or is suitable for landfilling.

The ANDCO-TORRAX system has been sold and constructed in Western Europe $\therefore$ (4 installations), Japan (1 installation), and the U.S. ( 1 for MSW disposal and for simulating disposal of nuclear wastes at Orlando, FL) (4).

Occidental Research Corporation Flash Pyrolysis

The Rlash pyrolysis system developed by Occidental Research Corp. has been tested briefly in a demonstration plant constructed at El Cajon, California with funds coming primarily from Ocridental but with some support from EPA and San Diego County. This 200 TPD process (35) consists of pyrolysis of the shredded light organic fraction of MSW in a fast moving $\left(1400^{\circ} \mathrm{F}\right)$ gas and particle stream recycled from the char burner. This gas cools in the reactor to an average pyrolysis temperature of $950^{\circ} \mathrm{F}$ before entering a cyclone for removal of char to the char burners for recycling. Residence time in the reactor is about $5 \mathrm{sec}$. The gas continues to an oil quenching, decanting system for recovery of product oil and the remaining product gas is compressed and used as 1) an oxygen free transport gas, 2) as fuel for preheating combustion air in the char burner, and 3) as fuel in the afterburner. Again, low-product-gas temperature before combustion in the afterburner and front-end metals removal indicates low potential 
for trace metals emission after baghouse control. Conversion efficiencies are lower than other pyrolysis systems mentioned here partially because there is heating value left in the char. The recovered product oil can be mixed with No. 6 fuel oil and burned. The system was demonstrated at the E1 Cajon facility although extended continuous operation did not ensue. As a result, extensive air emissions testing did not take place.

\section{PYRO-SOL Indirect-Heated Pyrolysis}

The PYRO-SOL process is an indirect heated pyrolysis system currently used In a 50 TPD scale plant to dispose of an RDF obtained from an auto salvage operation. It also has been tested using MSW and wood chips as feedstock (33). The system consists of primary shredding and then feeding through an air lock into a sealed horizontal pyrolysis reactor or "tunnel". A vibrating bed moves the feedstock from one end of the 60-ft length to the other at an average temperature of $1750^{\circ} \mathrm{F}$ with a slightly lower temperature at the air lock end than at the char collection end. The system is heated indirectly through tubes spaced over the vibrating bed (throughout the tunnel length). Product gas and waste heat also are recovered thruughout the reactor. The product gas leaves the reactor at approximately $1100^{\circ} \mathrm{F}$, is cleaned and quenched in a cyclone and wet scrubber and the cooled gas $(350-400 \mathrm{BTU} / \mathrm{SCF})$ is stored for use in a gas boiler/steam generator combination. The Bay Area Air Pollution Control District has tested the boiler when burning PYRO-SOL production gas. Test results show particulate emissions of $0.023 \mathrm{gr} / \mathrm{SCF}$ which $1 \mathrm{~s}$ well below the standard of $0.15 \mathrm{gr} / \mathrm{SCF}$ but this included noticeable rust from an infrequently used boiler (1). Because of this, these emission results are probably higher than would be the case in day to day boiler operating conditions. 
A high energy content char is produced from the waste and is processed via magnetic separation and air classification and a small percentage of it is used to filter scrubber wastewater. It may also have market value or possibly could be burned on site to produce more energy for indirect heating (33). 


\section{REFERENCES}

1. Air Pollution Control District, San Francisco, CA. "Sumnary of Stack Test Results on 6/20\%79 Test of PYRO-SOL Process (July 1979).

2. Ajax, R. "U..S. Environmental Protection Agency, Personal communication (January 1980).

3. Ames Laboratory Quarterly Report, Pollutant Characterization and Safety Research Division, Ames Laboratory, Ames, Iowa (April-June 1979).

4. "Andco-Torrax Process For Slagging Pyrolysis of Solid Waste", Andco, Inc., Buffalo, N.Y., company bulletin.

5. Barlow, K., Madison Gas and Electric; Madison, WI. Personal Communication (January 16, 1980).

6. Bowen, M.D., Smyly, E.D., Knight, J.A., Purdy, K.R. "A Vertical-Bed Pyrolysis System". Tech-Air Corp., Atlanta, GA. Proceedings of symposium sponsored by the Division of Environmental Chemistry at 175 th Meeting of ACS, Anaheim, CA (March 13-17, 1978), ACS Symposium Series

7. Combustion Engineering Associates, NY, NY. ECO-FUEL II Process, Unpublished company paper (undated).

8. Cornaby, B., Battelle- Columbus, personal communication (May 16, 1980).

9. Degler, G.H., "A Field Test Using Coa1: dRDF Blends in Spreader-Stoker Fired Boilers", Final Report for EPA Project 68-03-2426, Systech, Zenia, Ohio.

10. Devitt, T.W., "Air Pollution Emissions and Control Technology for WasteAs-Fuel Processes," PEDCO Environmental, Inc., Cincinnati, Ohio (October 1979).

11. Environmental Protection Agency, "Resource Recovery and Waste Reduction Activities - A Nationwide Survey, SW-432a (November 1979).

12. Freeman, H., U.S. Environmental Protection Agency, Unpublished information presented at the EPA-Sponsored Waste-To-Energy Technology Update 1980, Cincinnati, Ohio (April 15-16, 1980).

13. Golanbiewski, M., "Environmental Assessment of Waste-to-Energy Processes: Braintree Municipal Incineration," Final Report for EPA contract 60-022166 (April 1979).

14. Gorman, P.G., "St. Louis Demonstration Final Report: Power Plant Equipment, Facilities and Environmental Evaluation. U.S. Environmental Protection Agency Report EPA-600/2-77-1556 (December 1977). 
15. Greenberg, R.R., Zoller, W.H., Gordon, G.E. "Composition and Size Distribution of Particles Released in Refuse Incineration," Environmental Science and Technology, 12, 5, 566 (May 1978).

16. Griffeth, D.M., "The Recovery of Solid and Gaseous Resources from Industrial Wastes Using the PYRO-SOL Process," H.S. Haslam and Associates, (January 1979).

17. Ha11, J.L. et al., "Evaluation of the Ames Solid Waste Recovery System: Parts I, II, III. U.S. Environmental Protection Agency Report EPA 600/7-79-222 (October 1979).

18. Hasselriis, F., Combustinn Enginoering Assuclutes, Personal Communicatiun (Aprii 17, 1980).

19., Joensen, A.W, et a1., "Evaluation of Lhe Ames Solid Waste Recovery System: Refuste Processing Plant and Suspension-Fired Steam Generators." Draft Report for EPA Grant No. R803903-01-0 (Undated).

20. Joensen, A.W., Iowa State University, Personal Communication (January 17, 1979):

21. Lewis, D.F., "The Occurrences of Lead in Municipal Solid Waste," Proceedings of the Fifth Annual Research Symposium on Municipal Solid Waste: Resource Recovery," Orlando, FL, (March 26-29, 1979).

22. Martin, W.J., Weiand, H., "Practice of Heat Utilization from Refuse" Proceedings 8 th National Wastes Processing Conference, American Society of Mechanical Engineers, Chicago (May 7-10, 1978).

23. McDonough, T., "Refuse Energy System Co., Saugus, MA. Personal Communication (January $9 ; 1980)$ :

24. Moses, C.T., "Co-Disposal of Sludge and Refuse in a PUROX ${ }^{\text {TM }}$ Converter," Sol1d Wastes and Residues-Conversion by Advanced Processes, Proceedings of symposium sponsored by the Division of Environmental Chemistry at $175 \mathrm{th}$ Meeting of ACS, Anaheim, CA, (March 13-17, 1978), ACS Symposium Series \#76.

25. Mudge, L.K. and Rohrman, C.A., "Gasification of Solid Waste Fuels in a Fixed-Bed Gasifier," Proceedings of symposium sponsored by the Division of Environmental Chemistry at 175th Meeting of ACS, Anaheim, CA, (March 13-17, 1978), ACS Sympnsium Sericn $\$ 76$.

26. Néw York State Department of Environmental Conservation, "Stack Gas Results on Hempstead Resource Recovery Facility (April 30 and May 1, 1979).

27. Nowak, F,, "Development of the Kiener Pyrolysis System for Environmental Protection, Energy Recovery and Recycling," Proceedings, 8th National Waste Processing Conference, American Society of Mechanical Engineers, Chicago (May 7-10, 1978). 
28. Scarame11i, A.B., "Resource Recovery Research Development and Demonstration Plan," Mitre Corp. Technical Report MTR-79W00173 (October 1979).

29. Shelton, R.C., "Stagewise Gasification in a Multiple-Hearth Furnace for Co-Disposal of RDF and Sludge," Proceedings of symposium sponsored by the Division of Environmental Chemistry at 175th Meeting of ACS, Anaheim; CA, (March 13-17, 1978), ACS Symposium Series \#76.

30. Stanley, D.M., Andco Inc., Personal Communication (February 18, 1980).

31. Stevens, N., Detroit Edison, Personal Communication (January, 18, 1980).

32. Titus, G., City of Ames, Iowa, Personal Communication (September 1979).

33. Welty, J., PYRO-SOL, Inc., Personal Communication (Apri1 1980).

34. Williams, R.D., Gross, J.R., "Development of Pilot Plant Gasification Systems for the Conversion of Crop and Wood Residues to Thermal and Electrical Energy," Proceedings of symposium sponsored by the Division of Environmental Chemistry at 175th Meeting of ACS, Anaheim, CA, (March 13-17, 1978), ACS Symposium Series \#76.

35. Wilson, E.M., "Engineering and Economic Evaluation of Waste-to-Energy Systems," Final Report EPA Project 68-02-2101. The Ralph M. Parsons Co. (May 1978).

36. Wisconsin Electric Power Co. "Resource Recovery Project Particulate Emissions Evaluation Program," Final Report (February 1980). 


\section{THIS PAGE}

WAS INTENTIONALLY

LEFT BLANK 
APPENDIX A

STATUS OF AIR POLLUTION STANDARDS

APPLICABLE TO WASTE-TO-ENERGY PROCESSES

1. New Source Performance Standards (NSPS)

a. Co-combustion

New Source Performance Standards for particulate emissions from electric utility boilers larger than $250 \mathrm{mil} \mathrm{BTU} / \mathrm{hr}$ heat input (approxImately $10 \mathrm{~T} / \mathrm{hr}$ coal) recently have been revised downward by the U.S. Environmental Protection Agency from 0.1 to $0.031 \mathrm{~b} / 10^{6} \mathrm{BTU}$ (Al). The revised NSPS for industrial boilers are expected to be in a similar range. These standards are maximum and may be lowered significantly depending on regional and local off-set criteria. These standards also $\because$ are expected to apply to boilers co-firing RDF with other fossil fuels.

b. Mass-incineration

The U.S. EPA has proposed a new Federal NSPS of $0.03 \mathrm{gr} / \mathrm{dSCF}$ for incinerators greater than 50 tons per day. Current federal standards for mass incinerators is 0.08 grains per dry standard cubic foot (gr/dSCF) with many states having lower standards (Maryland $=0.03 \mathrm{gr} / \mathrm{dSCF}$; Massachusetts $=0.05 \mathrm{gr} / \mathrm{dSCF})(\mathrm{A} 2)$. New NSPS are 1ikely to be set by best available control technology.

Gaseous phase Chloride ( $\mathrm{HCl}$ ) apparently is being considered in the NSPS review required by the Clean Air Act Amendments of 1977 because of the increased occurrence of polyvinyl chloride (PVC) in municipal solid wastes. Heavy metals, particularly lead $(\mathrm{Pb})$ and cadmium ( $\mathrm{Cd})$, similarly are under review as possible NSPS's in the hazardous pollutant category. However, the fate of those proposals depend on the results of studies not yet completed by EPA. 
c. Pyrolysis

There currently are no NSPS specific to pyrolysis processes. These processes are expected as a minimum to meet indirect heat boiler emission standards or process weight emission standards which vary according to heat input.

2. Ambient Air Standards

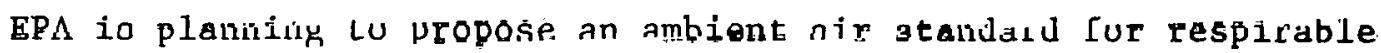
particulates in addition to the current amhient standard of $75 \mu \mathrm{m} / \mathrm{m}^{3}$ alluual geometric mean for total suspended particulates (A3). It is not known how this ultimately may affect NSPS for co-fired boilers, mass-incinerators or pyiulysis processes.

\section{REFERENCES}

Al. Title 40 CFR $60.42 a$

A2. Tit1e 40 CFR 60.52

43. Tit1e 40 CFR 30.6 